\title{
Influence of Organic Based Technologies on Soil Nutrient Status in Semi-Arid Yatta Sub-County, Kenya
}

\author{
R. N. Onwonga ${ }^{1}$, N. L. Namoi ${ }^{1} \&$ J. J. Lelei ${ }^{2}$ \\ ${ }^{1}$ Department of Land Resource Management and Agricultural Technology, University of Nairobi, Nairobi, \\ Kenya \\ ${ }^{2}$ Department of Crops, Horticulture and Soils, Egerton University, Njoro, Kenya \\ Correspondence: R. N. Onwonga, Department of Land Resource Management and Agricultural Technology, \\ University of Nairobi, P.O. Box 29053, Nairobi, Kenya. E-mail: onwongarichard@gmail.com
}

Received: January 25, 2015 Accepted: May 11, 2015 Online Published: July 15, 2015

doi:10.5539/jas.v7n8p56 URL: http://dx.doi.org/10.5539/jas.v7n8p56

\begin{abstract}
Declining soil fertility is the main cause of low and uncertain yields of sorghum and cassava traditional crops in arid and semi-arid areas of Kenya. Against this backdrop, this study investigated the effect of organic based technologies; application of organic fertilizers and integration of legumes in cassava and sorghum based cropping systems on soil chemical properties (Organic C, N, P and K). Field experiments were conducted in Katangi and Ikombe divisions of Yatta sub-County, Kenya during the short rain seasons (SRS) of 2010 and 2011 and long rain seasons (LRS) of 2011 and 2012. A randomised complete block design with a split plot arrangement was used. The main plots were three cropping systems: (i) intercropping (dolichos/cassava, dolichos/sorghum, pigeon pea/sorghum and pigeon pea/cassava); (ii) rotation (dolichos-cassava, dolichos-sorghum, pigeon pea-cassava and pigeon pea-sorghum); (iii) monocrop (cassava and sorghum). The split plots were organic fertilizers; Farm Yard manure (FYM), compost and control -no organic fertilizer added. Sorghum/dolichos+FYM had highest soil OC in LRS of 2011 at both sites and SRS of 2011 and 2010 at Katangi and Ikombe respectively. Cassava/dolichos+FYM had the highest soil OC in the SRS of 2011 and LRS of 2012 and 2011 at both sites. Sorghum/dolichos+FYM had highest soil N in LRS and SRS of 2011 in Katangi. Cassava-dolichos rotation accumulated highest soil N in SRS of 2010 and LRS of 2011 at both sites. Sorghum/dolichos intercrop accumulated higher soil P during the LRS of 2012 at both sites; and SRS of 2010 and LRS of 2011 in Katangi and Ikombe respectively. Cassava/dolichos intercrop produced higher soil P during the SRS of 2010 at both sites; and LRS of 2011 and SRS of 2011 in Katangi and Ikombe respectively. Higher soil $\mathrm{K}$ was observed under sorghum/dolichos intercrop in SRS of 2010 at both sites and LRS of 2011, SRS of 2011 and LRS of 2012 in Ikombe. Cassava/dolichos intercrop also had higher soil K during SRS of 2010, LRS of 2011 at both sites; LRS of 2012 at Katangi and SRS of 2011 at Ikombe. Application of FYM to sorghum/dolichos and cassava/pigeon pea intercrops is therefore a viable and sustainable trajectory to enhanced organic $\mathrm{C}$ and NPK levels in smallholder farming systems.
\end{abstract}

Keywords: compost, farm yard manure, intercropping, organic based technologies, rotation, staple crops

\section{Introduction}

The production potential of sorghum (Sorghum bicolor L.) and and cassava (Manihot esculenta Crantz) staple crops in semi-arid Yatta sub-county of Kenya is limited primarily by soil constraints, notably nitrogen and phosphorus deficiencies (Janssens, 2001; Shittu \& Fasina, 2004; Pholsen \& Sornsungnoen, 2004), the two critical nutrients for crop growth (Marschner, 1996). The deficiencies are attributable to unsustainable agricultural production practices by the small scale resource poor farmers. Nutrients lost from soil during crop production are not adequately replenished due to prohibitive cost of inorganic fertilizers (Kherallah et al., 2002; Smestad et al., 2002; Mwanga, 2004). Inappropriate management of these lands, further poses a risk for irreversible degradation (Smaling et al., 1997; Stoorvogel \& Smaling, 1998; Morris et al., 2007). This scenario thus calls for innovative approaches to restore soil fertility and manage the land sustainably.

Organic based technologies such as Integration of legumes either as intercrops or in rotation with other crops with the use of organic fertilizers can restore soil fertility and stabilize crop yields in marginal environments thereby providing a sustainable alternative to the use of inorganic fertilizers (Place et al., 2003; Ouédraogo et al., 
2001; Schlecht et al., 2006). Dual purpose, drought resistant legumes like dolichos (Lablab purpureus) and pigeon pea (Cajanus cajan (L.) Millspaugh) when incorporated into cropping systems with application of organic fertilizers can result in improvement of soil physical, chemical and biological properties and subsequently increase crop yields (Rao \& Mathuva, 2000; Giller, 2001; Cheruiyot et al., 2001). Organic fertilizers contain all essential nutrients plus carbon, the source of energy for soil biota that regulates nutrient cycling, and increase soil organic matter content (Sanchez et al., 1997). Long-term organic applications are extremely useful to build up better physical properties to favour water movement and storage in soils with low organic matter in semi-arid regions (Celik et al., 2004). Addition of organic materials on a regular basis is needed to prevent soil degradation and obtain sustainability in crop production under semi-arid climate conditions (Celik et al., 2010). The crops sorghum and cassava and legumes dolichos and pigeon pea, are drought tolerant and more resilient and adaptable to the prevailing biophysical conditions and changing climatic conditions in the arid and semi-arid Lands (ASALs) and require minimal inputs in their production (Shava, 2000, 2005; Asafo-Adjei, 2004). The legumes provide an important source of protein, have good commercial value and also offer an important opportunity for farmers to diversify their farming systems and improve soil fertility through biological nitrogen fixation (Jeranyama et al., 2000; Mapfumo \& Giller, 2001).

Despite their obvious utility to small-scale farmers, the ability of organic resources to supply nutrients to crops has not been fully integrated under arid-and semi-arid conditions of Yatta sub-County (L. M. Mugwira \& H. K. Murwira, 1997). Consequently, there is a need to understand and improve the efficiency of organic nutrient sources under site specific conditions. There is also insufficient information on the responses of soil to combined effects of different legumes integrated in cassava and sorghum cropping systems with application of organic fertilizers. The current study purposed to evaluate the effects of sorghum and cassava grown in rotation and/or intercropped with dolichos and pigeon pea with FYM and compost application on soil nutrient (C, N, P and K) status in semi-arid Yatta, Kenya.

\section{Materials and Methods}

\subsection{Study Site}

On-farm trials were conducted in Katangi and Ikombe divisions of Yatta sub-County in Eastern province, Kenya. The sub-county (700-800 m asl) lies in Zone V of the agro-climatic classification of Kenya (Jaetzold et al., 2006). It lies between latitude $0^{\circ} 03^{\prime}$ and $1^{\circ} 12^{\prime}$ South and longitude of $37^{\circ} 47^{\prime}$ and $38^{\circ} 57^{\prime}$ East. Yatta sub-County has a semi-arid climate with mean annual temperature ranging from $17{ }^{\circ} \mathrm{C}$ at night to $24{ }^{\circ} \mathrm{C}$ during the day and experiences bimodal rainfall. The study was conducted for two years (from October 2010 to August 2012) which constituted four seasons of experimentation. The two seasons in a year, which relate to the bi-annual rain seasons in Kenya, are the short (SRS) occurring from October to December and long rain season (LRS) from march/April to May (McSweeney et al., 2008; Figure 1).

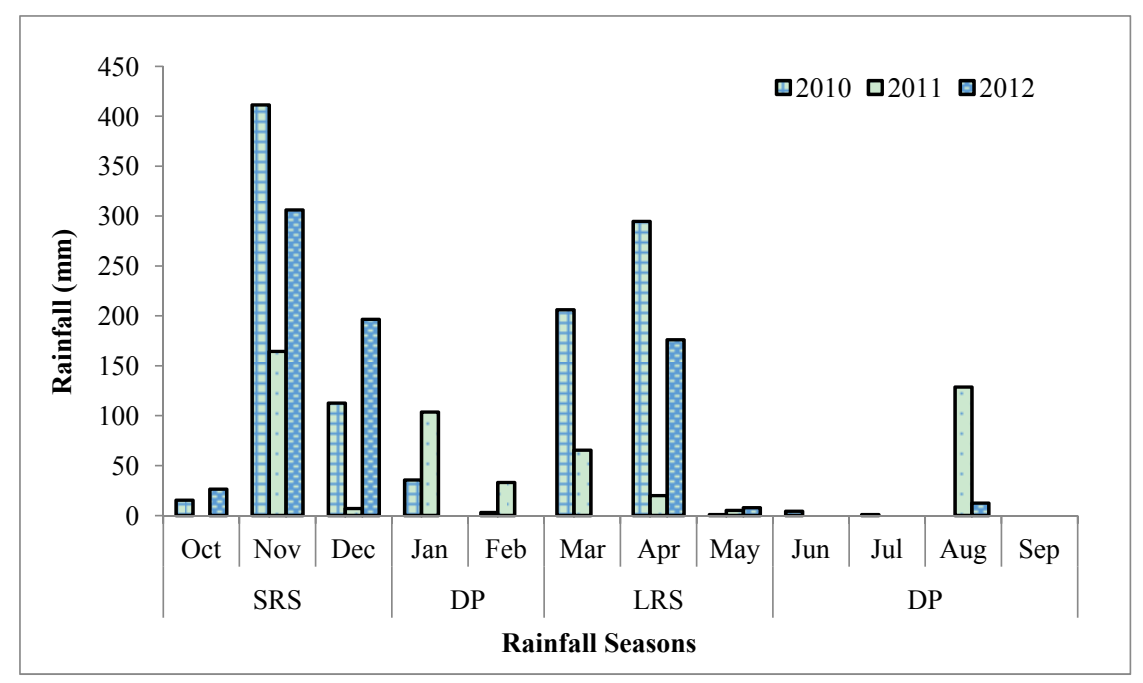

Figure 1. Total rainfall $(\mathrm{mm})$ received during the experimental period

Note. SRS: Short Rain Season; LRS: Long Rain Season; DP: Dry period (season without or with intermittent rains). 
The soils are predominantly Ferralsols (Kibunja et al., 2010) with nitrogen and phosphorous being the main limiting nutrients (Jaetzold et al., 2006) to crop production. The soil properties prior to experimental set-up in Katangi were of clay texture, moderate bulk density (Hazelton \& Murphy, 2007) and had according to Landon (1991) soil nutrient classification method; moderate organic C, low nitrogen, high potassium and low phosphorus levels (Table 1). Similarly, for Ikombe, the initial soil properties were: sandy clay loam texture, low bulk density (Hazelton \& Murphy, 2007), low organic carbon, low nitrogen, high phosphorous and high potassium (Table 1).

Table 1. Initial physical and chemical soil properties at the experimental sites

\begin{tabular}{llllll}
\hline Soil physical properties & Katangi & Ikombe & Soil Chemical properties & Katangi & Ikombe \\
\hline Bulk density $\left(\mathrm{g} \mathrm{cm}^{-3}\right)$ & 1.36 & 1.11 & $\mathrm{pH}\left(\mathrm{H}_{2} \mathrm{O}\right)$ & 6.31 & 6.49 \\
Sand (\%) & 40 & 58 & & & \\
Silt (\%) & 17 & 19 & $\mathrm{EC}\left(\mathrm{dsm}^{-1}\right)$ & 0.2 & 0.2 \\
Clay (\%) & 43 & 23 & Organic C $(\%)$ & 1.17 & 0.74 \\
Textural class & Clay & Sandy clay loam & $\mathrm{N}(\%)$ & 0.18 & 0.09 \\
& & & $\mathrm{Na}(\mathrm{cmol} / \mathrm{kg})$ & 0.38 & 0.38 \\
& & & $\mathrm{~K}(\mathrm{cmol} / \mathrm{kg})$ & 0.98 & 0.75 \\
& & & $\mathrm{CEC}(\mathrm{cmol} / \mathrm{kg})$ & 20.1 & 8.1 \\
& & & $\mathrm{P}(\mathrm{ppm})$ & 5.25 & 26.25 \\
\hline
\end{tabular}

\subsection{Treatments and Experimental Design}

The experimental setup was a randomized complete block design with a split plot arrangement replicated thrice. The main plots $(10 \mathrm{~m} \times 10 \mathrm{~m})$ were cropping systems; monocropping (sorghum or cassava), intercropping and rotation [where sorghum and cassava (TC) were either rotated or intercropped with either dolichos or pigeon pea. The split-plots $(3 \mathrm{~m} \times 10 \mathrm{~m})$ were organic fertilizer types; compost (COMP) and farmyard manure (FYM), and a control (CTRL - without organic fertilizer). This resulted in fifteen treatment combinations (Table 2) for each test crop.

Table 2. Treatments and treatment combinations

\begin{tabular}{lll}
\hline Mono-cropping & Intercropping & Crop rotation \\
\hline TC + FYM & TC/Dolichos + FYM & Dolichos - TC + FYM \\
TC + COMP & TC/Dolichos + COMP & Dolichos - TC + COMP \\
TC + CTRL & TC/Dolichos + CTRL & Dolichos - TC + CTRL \\
& TC/Pigeon Pea + FYM & Pigeon Pea - TC + FYM \\
& TC/Pigeon pea + COMP & Pigeon Pea - TC + COMP \\
& TC/Pigeon pea + CTRL & Pigeon pea - TC + CTRL \\
\hline
\end{tabular}

\subsection{Field Practices}

Primary land preparation was done using an oxen plough followed by secondary cultivation which involved use of hand implements. Organic inputs, FYM and compost, chemical properties in Table 3, were applied at rate of 5 $\mathrm{t} \mathrm{ha}^{-1}$ in respective treatments by placing into planting holes, mechanically created using hand hoes, and thoroughly mixed with soil before planting. The legumes were planted in the SRS of 2010 and 2011 in the crop rotation system. Test crops (sorghum and cassava) were planted during the long rain season of 2011 and 2012. For the intercrop and monocrops, across all seasons, either the TC or a legume/TC intercrops were planted. When intercropping and/or rotating cassava in the second season, the legumes were planted between the already established cassava plants since it takes longer (around 11 months) to reach physiological maturity. 
Table 3. Chemical properties of compost and FYM used in field experiment

\begin{tabular}{lllllll}
\hline \multirow{2}{*}{ Organic fertilizers } & \multicolumn{5}{c}{ Chemical Properties } \\
\cline { 2 - 6 } & $\mathrm{N}(\%)$ & $\mathrm{P}(\%)$ & $\mathrm{K}(\%)$ & $\mathrm{OC}(\%)$ & $\mathrm{pH}\left(\mathrm{H}_{2} \mathrm{O}\right)$ & $\mathrm{C}: \mathrm{N}$ Ratio \\
\hline FYM & 2.71 & 1.01 & 3.9 & 35 & 8.6 & 12.92 \\
Compost & 2.55 & 0.74 & 1.81 & 35.6 & 9.26 & 13.96 \\
\hline
\end{tabular}

Planting operation was performed manually by direct placement of the seeds/cuttings into planting holes. Cassava (variety Muceliceli), sorghum (variety Gandam), pigeon pea (variety KAT 60/8), and dolichos (black variety) sole crops were planted at spacing of $1 \mathrm{~m} \times 1 \mathrm{~m}, 0.75 \mathrm{~m} \times 0.25 \mathrm{~m}, 0.75 \mathrm{~m} \times 0.30 \mathrm{~m}$, and $0.75 \mathrm{~m} \times 0.50$ $\mathrm{m}$, respectively. For the intercropping system, pigeon pea or dolichos were sown in rows between sorghum and cassava, at the same inter-planting distance as in the sole crops.

Immediately after harvesting, at physiological crop maturity, above ground biomass of all crops, except cassava, were chopped into small pieces and incorporated into soil in the same plots where they had been harvested from. Cassava biomass was removed in line with the prevailing practice where stems are used as planting material, firewood or sold as cuttings.

\subsection{Sampling of Soils and Organic Inputs}

Composite top soil $(0-15 \mathrm{~cm})$ samples for characterization of initial physical and chemical properties (Figure 1) were collected in a zig-zag manner from the entire experimental plot before cropping and application of treatments. Bulk density was determined on undisturbed soil from different points in the field using steel core rings of $100 \mathrm{~cm}^{3}$ volume (Blake \& Hartge, 1986). Samples $(0-15 \mathrm{~cm})$ for analysis of organic C, available P, exchangeable $\mathrm{K}$ and total $\mathrm{N}$, were collected from five randomly selected points of each plot and composited. In the sorghum based cropping systems, soil sampling was done at harvest (three months after planting) while for cassava this was done three months after planting as well as at harvest (eleven months after planting). The samples were packed in polythene bags and sealed for transportation to the laboratory. Soil samples for bulk density determination were oven dried for 24 hours at $105^{\circ} \mathrm{C}$ whereas those for other analyses were air dried in the laboratory. Approximately $1 \mathrm{~kg}$ samples of manure and compost were collected at approximately $45 \mathrm{~cm}$ from the heap surface and stored in plastic bags. Air dried samples were ground to pass through a $2 \mathrm{~mm}$ sieve for analysis of total N, P and $\mathrm{K}, \mathrm{pH}$ and organic $\mathrm{C}$ (Table 3).

\subsection{Analysis of Soil and Organic Fertilizers}

Soil texture was determined by the Bouyoucos hydrometer method (Bouyoucos, 1962). Bulk density was determined on undisturbed soil samples (Blake \& Hartge, 1986). $\mathrm{pH}$ was measured in a 1:2.5 (w/v) soil/water suspension using a digital $\mathrm{pH}$ meter (Mc Lean,1982). Organic carbon (organic C) was determined by dichromate oxidation (Nelson \& Sommers, 1982). Cation exchange capacity (CEC) was measured according to Rhoades (1982). Exchangeable $\mathrm{K}$ was extracted with $1.0 \mathrm{M}$-ammonium acetate at $\mathrm{pH} 7$ and measured by atomic adsorption spectrophotometer (CAnalytic jena). Electrical conductivity was measured using a digital conductivity meter. Organic $\mathrm{C}$ content of compost and manure was determined by the dry combustion procedure (Nelson \& Sommers, 1982). Total $\mathrm{P}$ and $\mathrm{K}$ of organic fertilizers were determined by ashing of compost and manure samples on filters at $550{ }^{\circ} \mathrm{C}$ followed by extraction with hydrochloric acid $(\mathrm{HCl})$. The $\mathrm{HCl}$ extract was then measured using an automatic absorption spectrophotometer according to the method of Murphy and Riley (1962). Total nitrogen of compost, manure and soil samples was determined by the Kjeldahl method (Bremner \& Mulvaney, 1982).

\subsection{Data Analysis}

Data was subjected to general analysis of variance using Genstat statistical software (Payne et al., 2009). Fisher's protected least significant difference (LSD) test was used to identify significant differences among treatment means $(\mathrm{P}<0.05)$.

\section{Results and Discussion}

\subsection{Influence of Cropping Systems and Organic Fertilizers on Soil Organic Carbon}

There were no significant interaction effects between organic fertilizers and cropping systems on soil organic C. In both Katangi and Ikombe, organic carbon in soil was higher with application of FYM compared to compost and control, in both sorghum and cassava based cropping systems (Figures 2 and 3 ). 

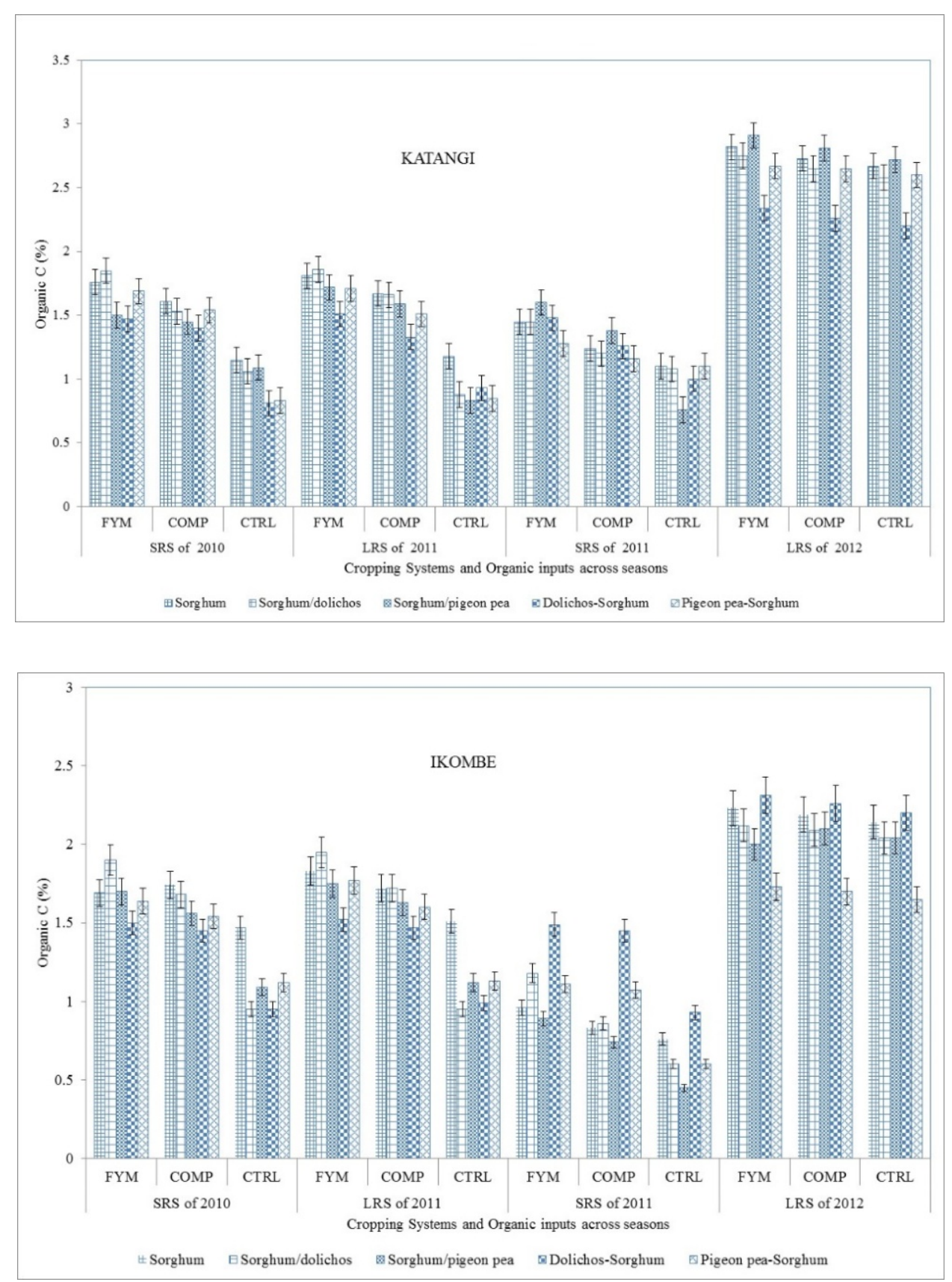

Figure 2. Soil Organic carbon as affected by cropping systems and organic fertilizers at Katangi and Ikombe in sorghum based cropping systems for four seasons 

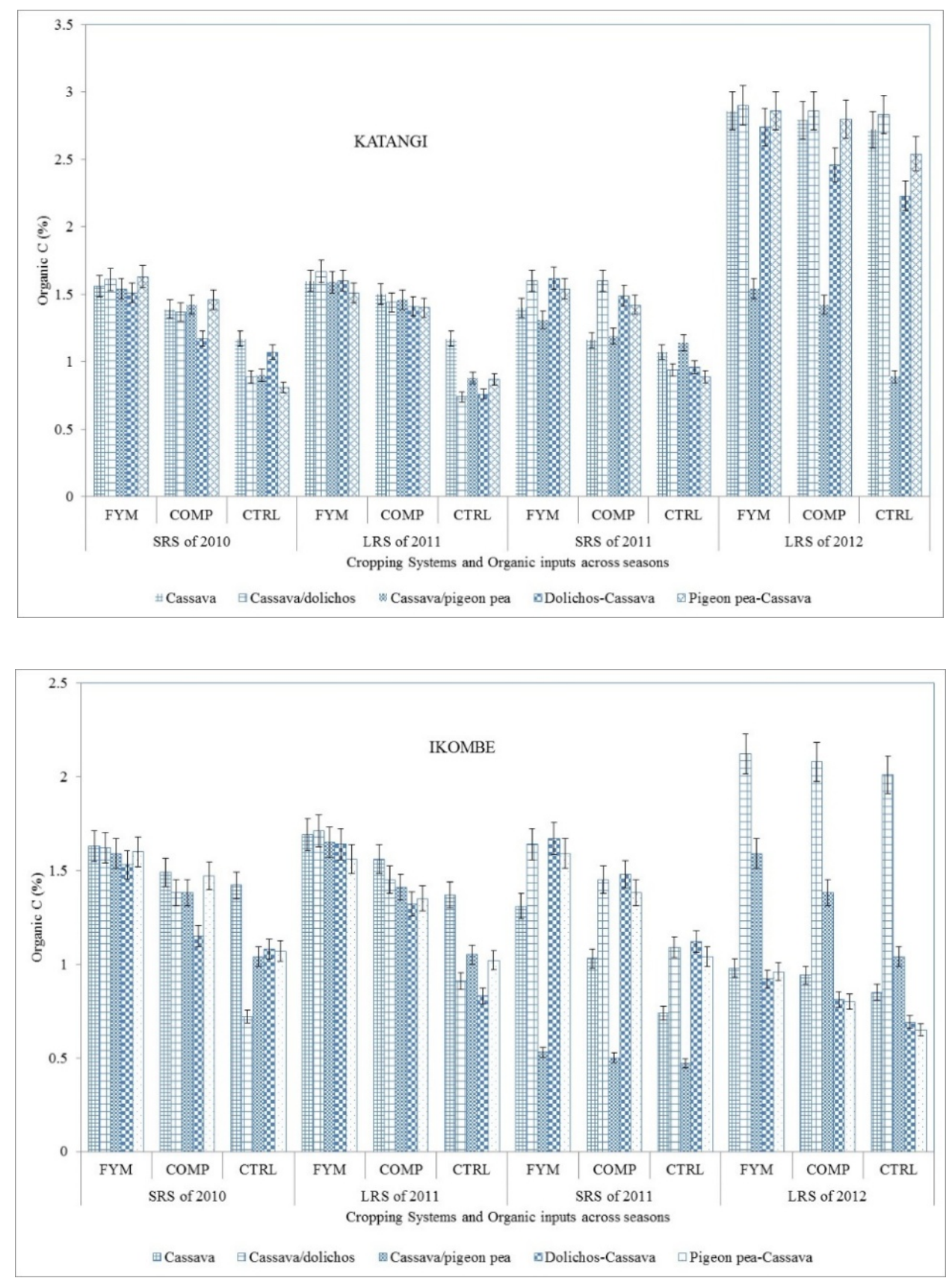

Figure 3. Soil Organic carbon as affected by cropping systems and organic fertilizers at Katangi and Ikombe in the cassava based cropping systems for four seasons

Higher organic C in soil where FYM was applied may be attributed to its slower decomposition rate and hence organic carbon build up. Addition of FYM has been shown to increase soil OC (Adekoyade \& Ogunkonya, 2011; Ali et al. (2009). Kapkiyai et al. (1999) reported that return of crop residue to soil may not be as effective in restocking soil organic $\mathrm{C}$ compared to addition of manure.

Sorghum/pigeon pea intercrop and pigeon pea-sorghum rotation did not significantly increase soil organic C compared to monocropping at both sites. Similar results were obtained in the cassava based cropping systems except during the SRS of 2011. Build up of organic C in soil can take a long time and this may partly explain lack of significant differences from monocropping system Changes in soil organic carbon are slow and typically takes five years (Baldock, 2009). Kouyaté et al. (2012) and Myaka et al. (2006) had also observed that integration of legumes within cropping systems did not improve soil organic C. Increased levels of decomposition, due to tillage may have also been another contributing factor. Tiessen et al. (2001) reported that 
soils in the tropics have little stable carbon and cultivation could enhance destabilisation and further losses of soil organic $\mathrm{C}$ even when residues are incorporated into soil regularly. Bwenya and Terokun (2001) reported that return of crop residues is effective in restocking soil organic $\mathrm{C}$.

Sorghum/dolichos intercrop had significantly $(\mathrm{P} \leq 0.05)$ higher soil organic $\mathrm{C}$ compared to sorghum/pigeon pea across organic fertilizers during the LRS of 2011 at both sites. Cassava/dolichos also had significantly $(\mathrm{P} \leq 0.05)$ higher organic C compared to cassava/pigeon pea intercrop during the LRS of 2011, SRS of 2011 and LRS of 2012 at both sites. Higher organic $\mathrm{C}$ under intercropping plots involving dolichos could be attributed to its higher biomass production offering less competition to the companion crop compared to pigeon pea. This may have, as well, allowed the companion crop to develop more biomass. Cheruiyot et al. (2001) also observed greater increases in biomass production in maize following dolichos compared to other legumes. The competitiveness of pigeon pea has been documented by Ito et al. (1993), noting that pigeon pea when intercropped with sorghum would outcompete sorghum for growth resources hence reducing sorghum yields, while Gichangi et al. (2006) also reported that pigeon pea tended to depress the leaf production of cassava.

Comparison of intercropping and rotation system showed that sorghum/dolichos intercrop had higher organic $\mathrm{C}$ compared to dolichos-sorghum rotation at both sites during SRS of 2010, LRS of 2012 at Katangi and LRS of 2011 at Ikombe. Cassava/dolichos intercrop also had higher soil organic C during LRS of 2012 than dolichos-cassava rotation at both sites. Additionally, organic C in Katangi in the cassava/dolichos intercrop was higher than in rotation system during SRS of 2010 and SRS of 2011 while in Ikombe the same pattern was observed during LRS of 2011. This may have been due to the high amount of biomass produced under intercropping leading to more residues available for decomposition. Ngome et al. (2012), though working with pinto peanut (Arachis pintoi) legume, showed that its use as permanent cover crop in maize plots could increase soil organic $\mathrm{C}$ because of its above and below ground biomass, residues of the companion maize as well as weed residues.

\subsection{Influence of Cropping Systems and Organic Fertilizers on Total N Content}

Total $\mathrm{N}$ was higher in sorghum than cassava plots and higher with integration of dolichos than pigeon peas. Further, significantly higher levels of total $\mathrm{N}$ were obtained with application of FYM than compost in all cropping systems and seasons (Tables 4, 5, and 7). Higher soil organic matter due to addition of FYM and compost has been previously proven to closely correlate with amount of $\mathrm{N}$ in soil (Kapkiyai et al., 1999). FYM treated plots had significantly $(\mathrm{P} \leq 0.05)$ higher $\mathrm{N}$ content compared to compost across cropping systems and seasons. This may be attributed to compost undergoing faster decomposition, and hence $\mathrm{N}$ release to the soil for crop uptake, and its effects may not be long lasting. It has also been observed that some ammonia-N may be lost through volatization in the process of composting hence reducing the content of $\mathrm{N}$ that could be supplied from compost compared to FYM (Rosen \& Bierman, 2014). Adekayode and Ogunkoya (2011) observed higher N content in plots treated with organic fertilizer attributing this observation to direct input of $\mathrm{N}$ and ability of manure to make $\mathrm{N}$ available for a long time due to slower release of $\mathrm{N}$ from the high residual pool.

Though not significant $(\mathrm{P} \leq 0.05)$, total $\mathrm{N}$ was highest during the SRS of 2011 (Tables 4 and 5) at both sites. This was contrary to expectation that low rainfall during this period could lead to lower biomass production and nitrogen fixation rate hence low soil $\mathrm{N}$. This was possibly because of the higher temperatures during this period which accelerated decomposition and subsequent $\mathrm{N}$ release. Because of limited rainfall, loss of mineralized $\mathrm{N}$ through leaching and erosion was reduced. It has previously been observed by Gachimbi et al. (2005) that most of the losses of $\mathrm{N}$ from soil could mainly be as a result of factors which are difficult to control such as erosion, leaching and volatization. 
Table 4. Total N (\%) as affected by cropping systems and organic fertilizers in sorghum based cropping systems at Katangi

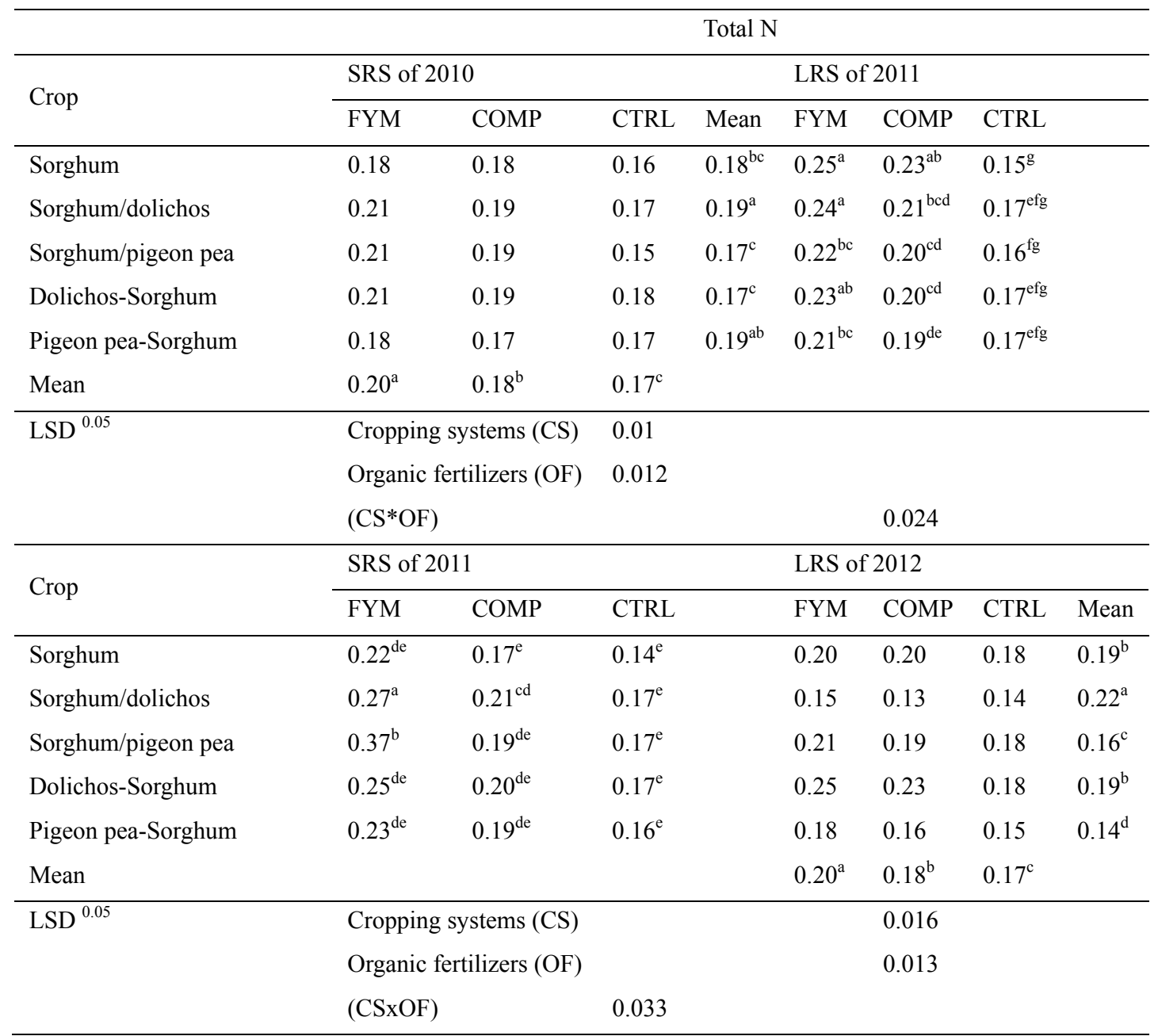

Note. Within rows and columns, means followed by the same letters are not significantly different at $\mathrm{P}<0.05$. In SRS of 2010 and LRS of 2011-main effects of CS and OF were significant but their interactions (CS*OF) were not significant; in LRS of 2011 and SRS of 2011, the CS*OF interactions were significant. 
Table 5. Total N (\%) as affected by cropping systems and organic fertilizers in sorghum cropping systems at Ikombe

\begin{tabular}{|c|c|c|c|c|c|c|c|}
\hline \multirow{3}{*}{ Crop } & \multicolumn{7}{|c|}{ Soil N } \\
\hline & \multicolumn{3}{|c|}{ SRS of 2010} & \multicolumn{4}{|c|}{ LRS of 2011} \\
\hline & FYM & COMP & CTRL & FYM & COMP & CTRL & Mean \\
\hline Sorghum & $0.13^{\mathrm{ef}}$ & $0.10^{\mathrm{hi}}$ & $0.11^{\mathrm{gh}}$ & 0.16 & 0.12 & 0.09 & $0.12^{\mathrm{bc}}$ \\
\hline Sorghum/dolichos & $0.15^{\mathrm{cd}}$ & $0.14^{\mathrm{de}}$ & $0.12^{\mathrm{fg}}$ & 0.21 & 0.17 & 0.12 & $0.17^{\mathrm{a}}$ \\
\hline Sorghum/pigeon pea & $0.14^{\mathrm{de}}$ & $0.10^{\mathrm{hi}}$ & $0.10^{\mathrm{hi}}$ & 0.18 & 0.13 & 0.10 & $0.14^{\mathrm{b}}$ \\
\hline Dolichos-Sorghum & $0.11 \mathrm{~g}^{\mathrm{h}}$ & $0.10^{\mathrm{hi}}$ & $0.09^{\mathrm{i}}$ & 0.12 & 0.12 & 0.09 & $0.11^{\mathrm{c}}$ \\
\hline Pigeon pea-Sorghum & $0.20^{\mathrm{a}}$ & $0.17^{\mathrm{b}}$ & $0.11^{\mathrm{gh}}$ & 0.19 & 0.12 & 0.10 & $0.14^{\mathrm{b}}$ \\
\hline mean & & & & $0.17^{\mathrm{a}}$ & $0.13^{\mathrm{b}}$ & $0.10^{\mathrm{c}}$ & \\
\hline \multirow[t]{4}{*}{$\operatorname{LSD}^{0.05}$} & \multicolumn{3}{|c|}{ Cropping systems (CS) } & & 0.014 & & \\
\hline & \multicolumn{3}{|c|}{ Organic fertilizers (OF) } & & \multicolumn{3}{|l|}{0.021} \\
\hline & \multicolumn{2}{|c|}{$\left(\mathrm{CS}^{*} \mathrm{OF}\right)$} & 0.019 & & & & \\
\hline & \multicolumn{2}{|l|}{$\mathrm{CV} \%$} & 23.9 & & \multicolumn{3}{|l|}{22.5} \\
\hline \multirow{2}{*}{ Crop } & \multicolumn{3}{|c|}{ SRS of 2011} & \multicolumn{4}{|c|}{ LRS of 2012} \\
\hline & FYM & COMP & CTRL & FYM & COMP & CTRL & Mean \\
\hline Sorghum & 0.11 & 0.08 & 0.05 & 0.10 & 0.07 & 0.04 & $0.07^{b}$ \\
\hline Sorghum/dolichos & 0.16 & 0.13 & 0.10 & 0.12 & 0.11 & 0.10 & $0.11^{\mathrm{a}}$ \\
\hline Sorghum/pigeon pea & 0.13 & 0.13 & 0.12 & 0.15 & 0.13 & 0.13 & $0.14^{\mathrm{a}}$ \\
\hline Dolichos-Sorghum & 0.13 & 0.10 & 0.08 & 0.15 & 0.14 & 0.11 & $0.14^{\mathrm{a}}$ \\
\hline Pigeon pea-Sorghum & 0.12 & 0.17 & 0.14 & 0.07 & 0.06 & 0.06 & $0.06^{\mathrm{b}}$ \\
\hline mean & $0.13^{\mathrm{a}}$ & $0.12^{\mathrm{a}}$ & $0.10^{\mathrm{b}}$ & $0.12^{\mathrm{a}}$ & $0.10^{\mathrm{b}}$ & $0.09^{\mathrm{b}}$ & \\
\hline \multirow[t]{2}{*}{$\operatorname{LSD}^{0.05}$} & \multicolumn{3}{|c|}{ Cropping systems (CS) } & & \multicolumn{3}{|l|}{0.031} \\
\hline & \multicolumn{2}{|c|}{$\begin{array}{l}\text { Organic fertilizers (OF) } \\
(\mathrm{CSxOF})\end{array}$} & 0.025 & & \multicolumn{3}{|l|}{0.014} \\
\hline
\end{tabular}

Note. Within rows and columns, means followed by the same letters are not significantly different at $\mathrm{P}<0.05$. SRS of 2010, LRS of 2011 and LRS 2012 the CS*OF interactions were significant. In the SRS of 2011, only main effects of OF were significant.

Sorghum/dolichos intercrop consistently had significantly $(\mathrm{P} \leq 0.05)$ higher total $\mathrm{N}$ compared to monocropping across sites and seasons (Tables 4 and 5). Higher total $\mathrm{N}$ in dolichos plots compared to monocrop could be as a result of nitrogen fixation by legume component. Higher $\mathrm{N}$ under sorghum/dolichos compared to sorghum/pigeon pea could be due to higher fixation of $\mathrm{N}$ by dolichos compared to pigeon pea as well as superior litter quality. Ayoub (1986) also reported higher rates of nitrogen release through biological fixing and decomposition under dolichos compared to pigeon pea. Higher soil $\mathrm{N}$ under intercropping with dolichos compared to rotation could be attributed to better nitrogen fixation that may occur under intercropping compared to when legumes are monocroped as well as higher amount of residue available for decomposition. It has also been reported that intercropping may result in increased amount of nitrogen fixed by legumes as the companion non-fixing crop utilizes excess nitrates in the root zone which would otherwise retard $\mathrm{N}$ fixation if they accumulate (Li et al., 2003).

Sorghum/pigeon pea intercrop did not produce significantly higher N compared to sorghum monocrop in SRS of 2010, LRS of 2011, SRS of 2011 and LRS of 2012 at Katangi as well as SRS of 2012 and LRS of 2011 at Ikombe (Tables 4 and 5). This could be as a result of competition for $\mathrm{N}$ between sorghum and pigeon pea component. IITA (1990) reported faster nutrient uptake and hence competition under intercropping systems. Another explanation could be that, apart from poor litter quality of pigeon pea, its deep roots may have fixed $\mathrm{N}$ beyond 
the sampled $15 \mathrm{~cm}$ depth hence underestimating its effects. Myaka et al. (2006) found that intercropping with pigeon pea may not show any significant impact on soil $\mathrm{N}$. He attributed this to among other factors, the deep rooting nature of pigeon pea leading to $\mathrm{N}$ occurring below the $0.15 \mathrm{~m}$ depth and impact of $\mathrm{N}$ from pigeon pea occurring in the resistant pool and therefore the effects investigated may more likely be attributed to the previous seasons. This conclusion is reinforced by the fact that even under rotation, pigeon pea fields still had lower soil $\mathrm{N}$ than sorghum monocrop in most of the seasons.

In the cassava based cropping systems $\mathrm{N}$ was low in Katangi (0.07-0.19) and Ikombe (0.02-0.1) across seasons (Tables 6 and 7). Low levels of $\mathrm{N}$ in the cassava based cropping systems may have been caused by export of $\mathrm{N}$ through removal of tubers and above ground biomass.

Table 6 . Total N (\%) as affected by cropping systems and organic fertilizers in cassava based cropping systems at Katangi

\begin{tabular}{|c|c|c|c|c|c|c|c|c|}
\hline \multirow{3}{*}{ Crop } & \multicolumn{8}{|c|}{ Soil N } \\
\hline & \multicolumn{4}{|c|}{ SRS of 2010} & \multicolumn{4}{|c|}{ LRS of 2011} \\
\hline & FYM & COMP & CTRL & Mean & FYM & COMP & CTRL & Mean \\
\hline Cassava & 0.13 & 0.07 & 0.07 & $0.09^{\mathrm{c}}$ & 0.12 & 0.07 & 0.16 & $0.12^{b}$ \\
\hline Cassava/dolichos & 0.10 & 0.13 & 0.10 & $0.11^{\mathrm{b}}$ & 0.11 & 0.08 & 0.13 & $0.11^{\mathrm{b}}$ \\
\hline Cassava/pigeon pea & 0.11 & 0.12 & 0.09 & $0.11^{\mathrm{b}}$ & 0.14 & 0.09 & 0.13 & $0.12^{\mathrm{b}}$ \\
\hline Dolichos-Cassava & 0.16 & 0.13 & 0.13 & $0.14^{\mathrm{a}}$ & 0.15 & 0.11 & 0.17 & $0.14^{\mathrm{a}}$ \\
\hline Pigeon pea-Cassava & 0.14 & 0.11 & 0.09 & $0.11^{\mathrm{b}}$ & 0.11 & 0.07 & 0.09 & $0.09^{\mathrm{c}}$ \\
\hline Mean & $0.13^{\mathrm{a}}$ & $0.11^{\mathrm{a}}$ & $0.09^{\mathrm{b}}$ & & $0.14^{\mathrm{a}}$ & $0.13^{\mathrm{a}}$ & $0.08^{\mathrm{b}}$ & \\
\hline \multirow[t]{3}{*}{$\mathrm{LSD}^{0.05}$} & \multicolumn{3}{|c|}{ Cropping systems (CS) } & 0.015 & & & \multicolumn{2}{|l|}{0.016} \\
\hline & \multirow{2}{*}{\multicolumn{3}{|c|}{$\begin{array}{l}\text { Organic fertilizers }(\mathrm{OF}) \\
(\mathrm{CS} * \mathrm{OF})\end{array}$}} & 0.017 & & & \multirow{2}{*}{\multicolumn{2}{|c|}{0.014}} \\
\hline & & & & & & & & \\
\hline \multirow{2}{*}{ Crop } & \multicolumn{4}{|c|}{ SRS of 2011} & \multicolumn{4}{|c|}{ LRS of 2012} \\
\hline & FYM & COMP & \multicolumn{2}{|l|}{ CTRL } & FYM & COMP & \multicolumn{2}{|l|}{ CTRL } \\
\hline Cassava & 0.12 & 0.18 & \multicolumn{2}{|l|}{0.15} & 0.14 & 0.12 & \multicolumn{2}{|l|}{0.10} \\
\hline Cassava/dolichos & 0.14 & 0.16 & \multicolumn{2}{|l|}{0.14} & 0.12 & 0.11 & \multicolumn{2}{|l|}{0.09} \\
\hline Cassava/pigeon pea & 0.16 & 0.13 & \multicolumn{2}{|l|}{0.11} & 0.11 & 0.12 & \multicolumn{2}{|l|}{0.09} \\
\hline Dolichos-Cassava & 0.16 & 0.19 & \multicolumn{2}{|l|}{0.16} & 0.13 & 0.10 & \multicolumn{2}{|l|}{0.07} \\
\hline Pigeon pea-Cassava & 0.11 & 0.12 & \multicolumn{2}{|l|}{0.09} & 0.15 & 0.13 & \multicolumn{2}{|l|}{0.09} \\
\hline Mean & & & & & $0.13^{\mathrm{a}}$ & $0.12^{\mathrm{a}}$ & $0.09^{\mathrm{b}}$ & \\
\hline \multirow[t]{3}{*}{$\mathrm{LSD}^{0.05}$} & \multicolumn{8}{|c|}{ Cropping systems (CS) } \\
\hline & \multirow{2}{*}{\multicolumn{4}{|c|}{ Organic fertilizers (OF) }} & & & \multirow{2}{*}{\multicolumn{2}{|c|}{0.019}} \\
\hline & & & & & & & & \\
\hline
\end{tabular}

Note. Within rows and columns, means followed by the same letters are not significantly different at $\mathrm{P}<0.05$. SRS of 2010and LRS of 2011, the main effects of CS and OF were significant. In SRS of 2011 the treatment effects were not significant whereas in the LRS of 2012, only main effects of CS were significant. 
Table 7. Total N (\%) as affected by cropping systems and organic fertilizers in cassava based cropping systems at Ikombe

\begin{tabular}{|c|c|c|c|c|c|c|c|c|}
\hline \multirow{3}{*}{ Crop } & \multicolumn{8}{|c|}{ Soil N } \\
\hline & \multicolumn{4}{|c|}{ SRS of 2010} & \multicolumn{4}{|c|}{ LRS of 2011} \\
\hline & FYM & COMP & CTRL & Mean & FYM & COMP & CTRL & Mean \\
\hline Cassava & 0.04 & 0.04 & 0.03 & $0.03^{\mathrm{c}}$ & 0.07 & 0.05 & 0.02 & $0.05^{\mathrm{b}}$ \\
\hline Cassava/dolichos & 0.08 & 0.04 & 0.03 & $0.05^{\mathrm{bc}}$ & 0.11 & 0.07 & 0.04 & $0.08^{\mathrm{a}}$ \\
\hline Cassava/pigeon pea & 0.08 & 0.04 & 0.06 & $0.06^{\mathrm{b}}$ & 0.11 & 0.07 & 0.06 & $0.08^{\mathrm{a}}$ \\
\hline Dolichos-Cassava & 0.10 & 0.08 & 0.07 & $0.08^{\mathrm{a}}$ & 0.12 & 0.10 & 0.05 & $0.09^{\mathrm{a}}$ \\
\hline Pigeon pea-Cassava & 0.08 & 0.05 & 0.07 & $0.06^{\mathrm{b}}$ & 0.05 & 0.03 & 0.03 & $0.04^{\mathrm{b}}$ \\
\hline Mean & $0.07^{\mathrm{a}}$ & $0.05^{\mathrm{b}}$ & $0.05^{\mathrm{b}}$ & & $0.09^{\mathrm{a}}$ & $0.07^{\mathrm{b}}$ & $0.04^{\mathrm{c}}$ & \\
\hline \multirow[t]{3}{*}{$\mathrm{LSD}^{0.05}$} & \multicolumn{3}{|c|}{ Cropping systems (CS) } & 0.017 & & & & 0.017 \\
\hline & \multirow{2}{*}{\multicolumn{3}{|c|}{$\begin{array}{l}\text { Organic fertilizers }(\mathrm{OF}) \\
(\mathrm{CS} * \mathrm{OF})\end{array}$}} & 0.016 & & & & 0.017 \\
\hline & & & & & & & & \\
\hline \multirow{2}{*}{ Crop } & \multicolumn{4}{|c|}{ SRS of 2011} & \multicolumn{4}{|c|}{ LRS of 2012} \\
\hline & FYM & COMP & CTRL & & FYM & COMP & CTRL & Mean \\
\hline Cassava & 0.08 & 0.07 & 0.04 & & 0.04 & 0.04 & 0.02 & $0.04^{\mathrm{b}}$ \\
\hline Cassava/dolichos & 0.11 & 0.09 & 0.09 & & 0.08 & 0.05 & 0.04 & $0.06^{\mathrm{a}}$ \\
\hline Cassava/pigeon pea & 0.06 & 0.04 & 0.03 & & 0.08 & 0.04 & 0.05 & $0.06^{\mathrm{a}}$ \\
\hline Dolichos-Cassava & 0.09 & 0.09 & 0.10 & & 0.03 & 0.03 & 0.02 & $0.03^{\mathrm{b}}$ \\
\hline Pigeon pea-Cassava & 0.08 & 0.04 & 0.05 & & 0.03 & 0.02 & 0.01 & $0.02^{\mathrm{b}}$ \\
\hline Mean & $0.09^{\mathrm{a}}$ & $0.07^{\mathrm{b}}$ & $0.06^{\mathrm{b}}$ & & $0.05^{\mathrm{a}}$ & $0.04^{\mathrm{b}}$ & $0.03^{\mathrm{b}}$ & \\
\hline \multirow[t]{3}{*}{$\mathrm{LSD}^{0.05}$} & \multicolumn{4}{|c|}{ Cropping systems (CS) } & & & & 0.018 \\
\hline & \multirow{2}{*}{\multicolumn{3}{|c|}{$\begin{array}{l}\text { Organic fertilizers }(\mathrm{OF}) \\
(\mathrm{CS} * \mathrm{OF})\end{array}$}} & 0.012 & & & & 0.012 \\
\hline & & & & & & & & \\
\hline
\end{tabular}

Note. Within rows and columns, means followed by the same letters are not significantly different at $\mathrm{P}<0.05$. In SRS of 2010, LRS of 2012and LRS of 2011, main effects of CS and OF were significant. In SRS of 2011, only main effects of OF were significant.

Pypers et al. (2011) had also observed high nutrient mining under cassava production. Soil N was higher in sorghum than cassava plots and higher with integration of dolichos than pigeon peas across sites and seasons. Similar to sorghum cropping systems, soil $\mathrm{N}$ levels reduced relative to initial values with most reduction being in the control plots probably due to absence of direct input of $\mathrm{N}$ from FYM and compost as well as low organic matter (OM) content. FYM applied plots also had higher N levels compared to compost. Dolichos-cassava rotation yielded significantly $(\mathrm{P} \leq 0.05)$ higher soil $\mathrm{N}$ values during the SRS of 2010 and LRS of 2011 at both sites compared to intercropping and monocropping. Lower soil $\mathrm{N}$ under intercropping could be as a result of higher levels of competition for nutrients under intercropping systems (IITA, 1990). Rotation with dolichos yielded higher soil $\mathrm{N}$ compared to monocropping mainly due to symbiotic nitrogen fixation by legumes. The ability of legumes to fix N symbiotically has been previously observed by Baldwin and Creamer (2014). In a study on effect of organic based nutrient strategies on nutrient availability, a higher $\mathrm{N}$ content was observed following lablab and was partly attributed to its deep root systems that captured nitrate from the subsoil (Lelei et al., 2009). Similarly, pigeon pea has a vigorous root system, with great capacity to explore large soil volumes and recycle nutrients from the deeper soil profiles (Adjei-Nsiah, 2012).

\subsection{Influence of Cropping Systems and Organic Fertilizers on Soil P Content}

Soil $\mathrm{P}$ values increased significantly $(\mathrm{P} \leq 0.05)$ in comparison to initial values at beginning of experiment (Figure 1) during the SRS of 2010 and LRS of 2011 across all cropping systems and sites (Tables 8, 9, 10 and 11). 
Table 8. Soil P (ppm) as affected by cropping systems and organic fertilizers in sorghum based cropping systems at Katangi

\begin{tabular}{|c|c|c|c|c|c|c|c|c|}
\hline \multirow{3}{*}{ Crop } & \multicolumn{8}{|c|}{ Soil P } \\
\hline & \multicolumn{4}{|c|}{ SRS of 2010} & \multicolumn{4}{|c|}{ LRS of 2011} \\
\hline & FYM & COMP & CTRL & Mean & FYM & COMP & CTRL & \\
\hline Sorghum & 27.31 & 25.15 & 25.73 & $31.80^{\mathrm{b}}$ & $34.03^{b}$ & $31.64^{\mathrm{c}}$ & $29.44^{\mathrm{e}}$ & \\
\hline Sorghum/dolichos & 28.54 & 26.65 & 23.11 & $41.70^{\mathrm{a}}$ & $37.04^{\mathrm{a}}$ & $34.23^{\mathrm{b}}$ & $31.05^{\mathrm{c}}$ & \\
\hline Sorghum/pigeon pea & 33.93 & 32.04 & 29.43 & $26.16^{\mathrm{c}}$ & $28.81^{\mathrm{e}}$ & $26.72^{\mathrm{g}}$ & $23.14^{\mathrm{j}}$ & \\
\hline Dolichos-Sorghum & 43.67 & 41.82 & 39.60 & $26.07^{\mathrm{c}}$ & $27.35^{\mathrm{fg}}$ & $26.87^{\mathrm{g}}$ & $25.72^{\mathrm{hi}}$ & \\
\hline Pigeon pea-Sorghum & 27.06 & 26.59 & 24.82 & $26.10^{\mathrm{c}}$ & $29.50^{\mathrm{de}}$ & $25.21^{\mathrm{i}}$ & $23.32^{\mathrm{j}}$ & \\
\hline Mean & $32.10^{\mathrm{a}}$ & $30.45^{\mathrm{b}}$ & $28.54^{\mathrm{c}}$ & & & & & \\
\hline \multirow[t]{3}{*}{$\mathrm{LSD}^{0.05}$} & \multicolumn{2}{|c|}{ Cropping systems (CS) } & 0.611 & & & & & \\
\hline & \multicolumn{2}{|c|}{ Organic fertilizers (OF) } & 0.89 & & & & & \\
\hline & \multicolumn{3}{|c|}{$(\mathrm{CS} * \mathrm{OF})$} & & & \multicolumn{3}{|c|}{0.83} \\
\hline \multirow{2}{*}{ Crop } & \multicolumn{4}{|c|}{ SRS of 2011} & \multicolumn{4}{|c|}{ LRS of 2012} \\
\hline & FYM & COMP & CTRL & & FYM & COMP & CTRL & Mean \\
\hline Sorghum & $34.77^{\mathrm{ab}}$ & $32.01^{\mathrm{bc}}$ & $29.84^{\text {cd }}$ & & 31.60 & 28.64 & 27.34 & $29.19^{b}$ \\
\hline Sorghum/dolichos & $23.18^{\mathrm{ef}}$ & $20.19^{\mathrm{fg}}$ & $16.62^{\mathrm{g}}$ & & 37.28 & 34.86 & 32.15 & $34.76^{\mathrm{a}}$ \\
\hline Sorghum/pigeon pea & $26.05^{\mathrm{de}}$ & $37.07^{\mathrm{a}}$ & $32.37^{\mathrm{bc}}$ & & 32.00 & 29.69 & 27.94 & $29.88^{b}$ \\
\hline Dolichos-Sorghum & $25.84^{\mathrm{de}}$ & $23.09^{\mathrm{ef}}$ & $18.99^{\mathrm{fg}}$ & & 20.83 & 20.09 & 19.24 & $20.06^{\mathrm{c}}$ \\
\hline Pigeon pea-Sorghum & $21.76^{\mathrm{ef}}$ & $18.79^{\mathrm{fg}}$ & $16.08^{\mathrm{g}}$ & & 33.59 & 30.78 & 29.48 & $31.28^{\mathrm{b}}$ \\
\hline Mean & & & & & $31.06^{\mathrm{c}}$ & $28.81^{\mathrm{b}}$ & $27.23^{\mathrm{c}}$ & \\
\hline \multirow[t]{3}{*}{$\mathrm{LSD}^{0.05}$} & \multicolumn{4}{|c|}{ Cropping systems (CS) } & & & \multicolumn{2}{|l|}{2.09} \\
\hline & \multicolumn{4}{|c|}{ Organic fertilizers (OF) } & & & \multirow{2}{*}{\multicolumn{2}{|c|}{0.92}} \\
\hline & $(\mathrm{CS} * \mathrm{OH}$ & & 4.694 & & & & & \\
\hline
\end{tabular}

Note. Within rows and columns, means followed by the same letters are not significantly different at $\mathrm{P}<0.05$. LRS of 2011, SRS of 2011 and LRS of 2012, CS*OF interactions were significant whereas in SRS of 2010, main effects of CS and OF were significant. 
Table 9. Soil P (ppm) as affected by cropping systems and organic fertilizers in sorghum based cropping systems at Ikombe

\begin{tabular}{|c|c|c|c|c|c|c|c|}
\hline \multirow{3}{*}{ Crop } & \multicolumn{7}{|c|}{ Soil P } \\
\hline & \multicolumn{3}{|c|}{ SRS of 2010} & \multicolumn{4}{|c|}{ LRS of 2011} \\
\hline & FYM & COMP & CTRL & FYM & COMP & CTRL & Mean \\
\hline Sorghum & $34.70^{\mathrm{c}}$ & $35.04^{\mathrm{c}}$ & $31.23^{\mathrm{d}}$ & 27.77 & 27.36 & 26.76 & $33.41^{b}$ \\
\hline Sorghum/dolichos & $43.65^{\mathrm{a}}$ & $41.73^{\mathrm{b}}$ & $42.32^{\mathrm{b}}$ & 27.83 & 27.53 & 25.31 & $42.44^{\mathrm{a}}$ \\
\hline Sorghum/pigeon pea & $27.76^{\mathrm{e}}$ & $27.32^{\mathrm{ef}}$ & $25.19^{\text {gh }}$ & 34.91 & 34.09 & 31.22 & $26.50^{\mathrm{d}}$ \\
\hline Dolichos-Sorghum & $27.75^{\mathrm{e}}$ & $27.37^{\text {ef }}$ & $26.71^{\text {ef }}$ & 43.69 & 41.81 & 41.81 & $27.29^{\mathrm{c}}$ \\
\hline Pigeon pea-Sorghum & $27.50^{\mathrm{ef}}$ & $26.31^{\mathrm{fg}}$ & $24.19^{\mathrm{h}}$ & 27.71 & 26.6 & 25.18 & $26.89^{\mathrm{dc}}$ \\
\hline Mean & & & & $32.38^{\mathrm{a}}$ & $31.48^{\mathrm{b}}$ & $30.06^{\mathrm{c}}$ & \\
\hline \multirow[t]{3}{*}{$\operatorname{LSD}^{0.05}$} & \multicolumn{3}{|c|}{ Cropping systems (CS) } & & & 0.526 & \\
\hline & \multicolumn{3}{|c|}{ Organic fertilizers (OF) } & & & \multicolumn{2}{|l|}{0.59} \\
\hline & $(\mathrm{CS} * \mathrm{OF}$ & & 1.319 & & & & \\
\hline \multirow{2}{*}{ Crop } & \multicolumn{3}{|c|}{ SRS of 2011} & \multicolumn{4}{|c|}{ LRS of 2012} \\
\hline & FYM & COMP & CTRL & FYM & COMP & CTRL & Mean \\
\hline Sorghum & $35.38^{\mathrm{c}}$ & $34.31^{\mathrm{cd}}$ & $31.39^{f}$ & 24.29 & 22.69 & 21.58 & $32.13^{\mathrm{a}}$ \\
\hline Sorghum/dolichos & $39.37^{\mathrm{a}}$ & $34.63^{\mathrm{cd}}$ & $31.74^{\mathrm{ef}}$ & 31.11 & 29.97 & 28.06 & $30.79^{\mathrm{a}}$ \\
\hline Sorghum/pigeon pea & $40.23^{\mathrm{a}}$ & $37.08^{\mathrm{b}}$ & $33.26^{\mathrm{d}}$ & 35.77 & 31.65 & 28.98 & $30.97^{\mathrm{a}}$ \\
\hline Dolichos-Sorghum & $27.73^{\text {gh }}$ & $27.34^{\mathrm{h}}$ & $26.70^{\mathrm{h}}$ & 33.05 & 30.84 & 28.48 & $22.85^{\mathrm{b}}$ \\
\hline Pigeon pea-Sorghum & $26.39^{\mathrm{h}}$ & $22.51^{\mathrm{i}}$ & $20.52^{\mathrm{j}}$ & 33.97 & 30.68 & 28.25 & $29.71^{\mathrm{a}}$ \\
\hline Mean & & & & $31.64^{\mathrm{a}}$ & $29.17^{\mathrm{b}}$ & $27.07^{\mathrm{c}}$ & \\
\hline \multirow[t]{3}{*}{$\operatorname{LSD}^{0.05}$} & \multicolumn{5}{|c|}{ Cropping systems (CS) } & \multicolumn{2}{|l|}{3.091} \\
\hline & \multicolumn{3}{|c|}{ Organic fertilizers (OF) } & & & \multirow{2}{*}{\multicolumn{2}{|c|}{0.816}} \\
\hline & $(\mathrm{CS} * \mathrm{OF}$ & & 1.467 & & & & \\
\hline
\end{tabular}

Note. Within rows and columns, means followed by the same letters are not significantly different at $\mathrm{P}<0.05$. In SRS of 2010 and LRS of 2012, CS*OF interactions were significant. In LRS of 2011 and SRS of 2011 main effects of CS and OF were significant.

This could be due to direct input of organic fertilizers, as well as decomposition of organic residues that were ploughed into the soil. The fact that $\mathrm{P}$ is an immobile element and has high residual effect, would have as well contributed to its elevated levels in the soil. It has previously been shown that decomposing crop residue can release organic acids, which may increase the availability of bound $\mathrm{P}$ hence increasing it content in the soil (Zsolnay \& Gorlitz, 1994). There was however a significant decline in soil P at Katangi during the SRS of 2011 in the sorghum based cropping systems (Table 7). In the cassava based cropping systems, a significant decline in soil P also occurred across cropping systems in the LRS of 2012 at both sites (Tables 10 and 11) and in the SRS of 2011 at Katangi (Table 10).

Decline in soil $\mathrm{P}$ could be as a result of lower biomass productivity due to reduced amount of rainfall which ultimately affected the amount of residues available for decomposition. Significantly $(\mathrm{P} \leq 0.05)$ higher soil $\mathrm{P}$ levels were observed with FYM application compared to compost and control experiment respectively across all cropping systems and seasons. Higher levels of soil P under FYM and compost could be as a result of direct input of $\mathrm{P}$ into the soil through decomposition of organic fertilizers. It has been previously observed by Eghball and Power (1999) that application of FYM and compost could improve P status of soil. Further increases in soil $\mathrm{P}$ could have been caused by mineralization of high amounts of crop residues that had been returned to soil compared to the control. Higher soil P under FYM compared to compost could be attributed to the slower decomposition rates of the latter and hence slower release of $\mathrm{P}$ over time as well as decomposition of higher 
amounts of crop residue that were produced with FYM application.

Table 10. Soil P (ppm) as affected by cropping systems and organic fertilizers in cassava based cropping systems at Katangi

\begin{tabular}{|c|c|c|c|c|c|c|c|c|}
\hline \multirow{3}{*}{ Crop } & \multicolumn{8}{|c|}{ Soil P } \\
\hline & \multicolumn{4}{|c|}{ SRS of 2010} & \multicolumn{4}{|c|}{ LRS of 2011} \\
\hline & FYM & COMP & CTRL & Mean & FYM & COMP & CTRL & Mean \\
\hline Cassava & 26.26 & 23.83 & 20.72 & $23.60^{\mathrm{e}}$ & 25.89 & 24.36 & 20.75 & $23.67^{\mathrm{d}}$ \\
\hline Cassava/dolichos & 38.80 & 38.17 & 33.98 & $36.98^{\mathrm{a}}$ & 38.78 & 37.2 & 32.34 & $36.11^{\mathrm{a}}$ \\
\hline Cassava/pigeon pea & 32.71 & 31.72 & 30.81 & $31.75^{\mathrm{c}}$ & 32.78 & 31.77 & 30.80 & $31.78^{b c}$ \\
\hline Dolichos-Cassava & 37.57 & 34.76 & 34.42 & $35.58^{\mathrm{d}}$ & 38.66 & 35.56 & 31.00 & $35.07^{\mathrm{ab}}$ \\
\hline Pigeon pea-Cassava & 28.25 & 26.14 & 23.15 & $25.85^{\mathrm{d}}$ & 32.69 & 25.17 & 30.84 & $29.56^{\mathrm{c}}$ \\
\hline Mean & $32.72^{\mathrm{a}}$ & $30.92^{\mathrm{b}}$ & $28.62^{\mathrm{c}}$ & & $33.76^{\mathrm{a}}$ & 30.81 & $29.14^{\mathrm{b}}$ & \\
\hline \multirow[t]{2}{*}{$\mathrm{LSD}^{0.05}$} & \multicolumn{2}{|c|}{ Cropping systems (CS) } & 1.004 & & & 3.829 & & \\
\hline & \multicolumn{2}{|c|}{ Organic fertilizers (OF) } & 1.375 & & & 2.323 & & \\
\hline \multirow{2}{*}{ Crop } & \multicolumn{4}{|c|}{ SRS of 2011} & \multicolumn{4}{|c|}{ LRS of 2012} \\
\hline & FYM & COMP & CTRL & & FYM & COMP & CTRL & Mean \\
\hline Cassava & $22.58^{\mathrm{d}}$ & $19.25^{\mathrm{e}}$ & $15.77^{\mathrm{f}}$ & & 31.47 & 29.17 & 26.07 & $28.91^{\mathrm{b}}$ \\
\hline Cassava/dolichos & $32.77^{\mathrm{ab}}$ & $31.12^{\mathrm{bc}}$ & $30.86^{\mathrm{c}}$ & & 31.17 & 29.57 & 28.23 & $29.66^{\mathrm{b}}$ \\
\hline Cassava/pigeon pea & $33.47^{\mathrm{a}}$ & $31.49^{b c}$ & $31.17^{\mathrm{bc}}$ & & 32.71 & 31.72 & 30.82 & $31.75^{\mathrm{a}}$ \\
\hline Dolichos-Cassava & $32.79^{\mathrm{ab}}$ & $31.14^{b c}$ & $30.88^{\mathrm{c}}$ & & 29.93 & 26.47 & 23.32 & $26.57^{\mathrm{c}}$ \\
\hline Pigeon pea-Cassava & $32.71^{\mathrm{ab}}$ & $31.72^{\mathrm{abc}}$ & $30.81^{\mathrm{c}}$ & & 32.19 & 29.34 & 28.18 & $29.90^{\mathrm{ab}}$ \\
\hline Mean & & & & & $31.49^{\mathrm{a}}$ & $29.25^{\mathrm{b}}$ & $27.32^{\mathrm{c}}$ & \\
\hline \multirow[t]{3}{*}{$\mathrm{LSD}^{0.05}$} & \multicolumn{4}{|c|}{ Cropping systems (CS) } & & 2.01 & & \\
\hline & \multicolumn{3}{|c|}{ Organic fertilizers (OF) } & & & 0.994 & & \\
\hline & $(\mathrm{CS} * \mathrm{OF}$ & & 1.754 & & & & & \\
\hline
\end{tabular}

Note. Within rows and columns, means followed by the same letters are not significantly different at $\mathrm{P}<0.05$. In SRS of 2010, LRS of 2011 and LRS of 2012, main effects of CS and OF were significant whereas in the SRS of 2011, CS*OF interactions were significant. 
Table 11. Soil P (ppm) as affected by cropping systems and organic fertilizers in cassava based cropping systems at Ikombe

\begin{tabular}{|c|c|c|c|c|c|c|c|}
\hline \multirow[b]{3}{*}{ Crop } & \multicolumn{7}{|c|}{ Soil P } \\
\hline & \multicolumn{4}{|l|}{ SRS of 2010} & \multicolumn{3}{|c|}{ LRS of 2011} \\
\hline & FYM & COMP & CTRL & Mean & FYM & COMP & CTRL \\
\hline Cassava & 25.99 & 24.06 & 21.99 & $24.02^{\mathrm{d}}$ & $26.06^{\mathrm{g}}$ & $24.55^{\mathrm{h}}$ & $21.55^{\mathrm{i}}$ \\
\hline Cassava/dolichos & 39.43 & 36.75 & 31.81 & $36.00^{\mathrm{a}}$ & $39.61^{\mathrm{a}}$ & $36.60^{\mathrm{b}}$ & $33.27^{\mathrm{d}}$ \\
\hline Cassava/pigeon pea & 34.83 & 32.23 & 31.34 & $32.80^{\mathrm{b}}$ & $34.88^{\mathrm{c}}$ & $32.06^{\mathrm{de}}$ & $31.35^{\mathrm{ef}}$ \\
\hline Dolichos-Cassava & 38.30 & 34.63 & 34.12 & $35.69^{\mathrm{a}}$ & $39.02^{\mathrm{a}}$ & $35.37^{\mathrm{c}}$ & $30.75^{\mathrm{f}}$ \\
\hline Pigeon pea-Cassava & 27.75 & 25.62 & 24.37 & $25.91^{\mathrm{c}}$ & $34.80^{\mathrm{c}}$ & $32.37^{\mathrm{de}}$ & $31.31^{\mathrm{ef}}$ \\
\hline Mean & $33.26^{\mathrm{a}}$ & $30.66^{\mathrm{b}}$ & $28.73^{\mathrm{c}}$ & & & & \\
\hline \multirow[t]{4}{*}{$\operatorname{LSD}^{0.05}$} & Cropping systems (CS) & 0.906 & & & & & \\
\hline & Organic fertilizers (OF) & 1.248 & & & & & \\
\hline & $(\mathrm{CS} * \mathrm{OF})$ & & & & & 1.223 & \\
\hline & \multicolumn{4}{|l|}{ SRS of 2011} & \multicolumn{3}{|c|}{ LRS of 2012} \\
\hline Crop & FYM & COMP & CTRL & Mean & FYM & COMP & CTRL \\
\hline Cassava & 34.25 & 32.17 & 29.13 & $31.85^{\mathrm{c}}$ & $28.34^{\mathrm{fg}}$ & $26.76^{\text {gh }}$ & $24.61^{\mathrm{i}}$ \\
\hline Cassava/dolichos & 34.89 & 32.29 & 31.37 & $32.85^{\mathrm{ab}}$ & $33.19^{b c}$ & $31.38^{\text {cde }}$ & $29.28^{\mathrm{ef}}$ \\
\hline Cassava/pigeon pea & 35.31 & 33.09 & 32.14 & $33.52^{\mathrm{a}}$ & $34.83^{\mathrm{ab}}$ & $32.23^{\mathrm{cd}}$ & $31.35^{\text {cde }}$ \\
\hline Dolichos-Cassava & 34.24 & 32.32 & 31.4 & $32.65^{\mathrm{b}}$ & $32.60^{\mathrm{cd}}$ & $29.64^{\mathrm{ef}}$ & $25.95^{\mathrm{hi}}$ \\
\hline Pigeon pea-Cassava & 34.83 & 32.23 & 31.34 & $32.80^{\mathrm{ab}}$ & $36.77^{\mathrm{a}}$ & $31.08^{\mathrm{de}}$ & $28.05^{\text {fgh }}$ \\
\hline Mean & $34.70^{\mathrm{c}}$ & $32.42^{\mathrm{b}}$ & $31.08^{\mathrm{a}}$ & & & & \\
\hline \multirow[t]{3}{*}{$\mathrm{LSD}^{0.05}$} & Cropping systems (CS) & 0.801 & & & & & \\
\hline & Organic fertilizers (OF) & 0.638 & & & & & \\
\hline & $(\mathrm{CS} * \mathrm{OF})$ & & & & & 2.101 & \\
\hline
\end{tabular}

Note. Within rows and columns, means followed by the same letters are not significantly different at $\mathrm{P}<0.05$. In LRS of 2011 and LRS of 2012, CS*OF interactions were significant whereas in SRS of 2010 and SRS of 2011only main effects of CS and OF were significant.

Monocropping sorghum led to significantly $(\mathrm{P} \leq 0.05)$ higher soil $\mathrm{P}$ compared to sorghum/pigeon pea intercrop, and rotation with either pigeon pea or dolichos during SRS of 2010 at both sites (Tables 8 and 9). Similar results were observed during the LRS and SRS of 2011 at both sites. Higher P in sorghum monocrop compared to sorghum/pigeon pea intercrop, pigeon pea-sorghum rotation and dolichos-sorghum rotation could be due to export of P to legume grains. Kouyaté et al. (2012) observed higher soil P under monocropped sorghum compared to rotation with legumes attributing this to export of $\mathrm{P}$ to grains. They further noted that $\mathrm{P}$ losses from soil increase with increasing grain yields due to most of the $\mathrm{P}$ being transported to the grain. Integration of legumes could also have resulted in less soil $\mathrm{P}$ due to higher uptake of $\mathrm{P}$ by legume crops, which is essential in BNF and root development (Cassman et al., 1981). Furthermore, it has been demonstrated that legumes can increase uptake of $\mathrm{P}$ for the companion crop when intercropped or rotated (Li et al., 2004; Nuruzzaman et al., 2005). Intercropping sorghum with dolichos however resulted in significantly $(\mathrm{P} \leq 0.05)$ higher soil $\mathrm{P}$ compared to either monocropping during the SRS of 2010 and LRS of 2012 at both sites and during LRS of 2012 at Katangi only. This was probably due to the ability of legumes to solubilize insoluble P. Higher P under legumes has also been reported by Bagayoko et al. (2000), Rusinamhodzi (2006) and Li et al. (2008) attributing this to mobilization of the sparingly soluble $\mathrm{P}$ by legume exudates. Addition of $\mathrm{P}$ through decomposition of residues could also be another avenue through which the P levels increased. Higher soil P when dolichos was used compared to pigeon pea may be due to higher biomass production under dolichos compared to pigeon pea hence more nutrient release upon decomposition. Higher rates of nutrient release under dolichos compared to pigeon 
pea have previously been observed by Ayoub (1986) who attributed this to better mineralization as a result of the conducive environment provided by the dolichos for microbial decomposition.

In the cassava based cropping systems, inclusion of legumes significantly $(\mathrm{P} \leq 0.05)$ increased soil $\mathrm{P}$ relative to cassava monocropping across all sites and seasons except during LRS of 2012 at Katangi where only dolichos-cassava rotation had significantly lower soil $\mathrm{P}$ than monocrop. High soil P under legume plots could be explained in terms of the solubilising effect of legume exudates on insoluble soil P ( $\mathrm{Li}$ et al., 2008; Bagayoko et al., 2000). Decomposing legume residues could also have contributed to increased soil $P$ either through release of organic acids which increase desorption of P (Ogunwole et al., 2009; Zsolnay \& Gorlitz, 1994) as opposed to monocrop where there was no legume residues returned to soil.

Intercropping cassava with legumes had higher soil P levels compared to rotation across seasons and sites though this was not significant during the LRS of 2011 at both sites and SRS of 2011 at Katangi (Tables 10 and 11). This is contrary to expectations that combined uptake of $\mathrm{P}$ under intercropping coupled with cassava biomass not being returned to the soil would have led to lower soil $\mathrm{P}$ under intercropping. A possible explanation could be that $\mathrm{P}$ uptake could have been enhanced under rotation compared to intercropping hence reduced soil $\mathrm{P}$ under rotation. Sierverding and Leihner (1984) found that rotating cassava with grain legumes could enhance occurrence of root vesicular-arbuscular (VA) mycorrhiza infection, which has the effect of increasing uptake of $\mathrm{P}$ from soil. This is especially under soils that are acidic and low in available P. Inclusion of dolichos resulted in higher soil $\mathrm{P}$ compared to pigeon pea probably due to more biomass and hence crop residue production and better quality litter of dolichos (Ayoub 1986).

\subsection{Influence of Cropping Systems and Organic Fertilizers on Soil K Content}

Soil K levels in sorghum cropping systems (Tables 12 and 13) were moderate at Ikombe $(0.53 \mathrm{cmol} / \mathrm{kg}$ to 1.21 $\mathrm{cmol} / \mathrm{kg})$ whereas at Katangi, they ranged from moderate $(0.93 \mathrm{cmol} / \mathrm{kg})$ to high $(2.23 \mathrm{cmol} / \mathrm{kg})$ according to Landon 1991. 
Table 12. Soil $\mathrm{K}(\mathrm{cmol} / \mathrm{kg})$ as affected by cropping systems and organic fertilizers in sorghum based cropping systems at Katangi low $=<0.2$; medium 0.2-6.0; high $>0.6$

\begin{tabular}{|c|c|c|c|c|c|c|c|}
\hline \multirow{3}{*}{ Crop } & \multicolumn{7}{|c|}{ Soil K } \\
\hline & \multicolumn{4}{|c|}{ SRS of 2010} & \multicolumn{3}{|c|}{ LRS of 2011} \\
\hline & FYM & COMP & CTRL & Mean & FYM & COMP & CTRL \\
\hline Sorghum & 0.99 & 1.05 & 0.85 & $0.96^{\mathrm{b}}$ & $0.88^{\mathrm{h}}$ & $1.02^{\mathrm{d}}$ & $0.88^{\mathrm{gh}}$ \\
\hline Sorghum/dolichos & 1.21 & 1.153 & 0.98 & $1.11^{\mathrm{a}}$ & $1.13^{\mathrm{a}}$ & $1.12^{\mathrm{ab}}$ & $0.93^{\text {fgh }}$ \\
\hline Sorghum/pigeon pea & 0.933 & 1.02 & 0.95 & $0.97^{\mathrm{b}}$ & $1.04^{\mathrm{cd}}$ & $1.05^{\mathrm{cd}}$ & $0.94^{\mathrm{fg}}$ \\
\hline Dolichos-Sorghum & 1.028 & 0.96 & 0.95 & $0.98^{\mathrm{b}}$ & $1.08^{\mathrm{abc}}$ & $0.95^{\mathrm{f}}$ & $0.97^{\mathrm{ef}}$ \\
\hline Pigeon pea-Sorghum & 1.012 & 0.99 & 0.91 & $0.97^{\mathrm{b}}$ & $1.07^{\mathrm{bcd}}$ & $1.06^{\mathrm{cd}}$ & $0.96^{\mathrm{f}}$ \\
\hline Mean & $1.04^{\mathrm{a}}$ & $1.03^{\mathrm{a}}$ & $0.93^{\mathrm{b}}$ & & & & \\
\hline \multirow[t]{3}{*}{$\operatorname{LSD}^{0.05}$} & \multicolumn{2}{|c|}{ Cropping systems (CS) } & 0.0754 & & & & \\
\hline & \multicolumn{2}{|c|}{ Organic fertilizers (OF) } & 0.0751 & & & & \\
\hline & \multicolumn{4}{|c|}{$(\mathrm{CS} * \mathrm{OF})$} & & & 0.0563 \\
\hline \multirow{2}{*}{ Crop } & \multicolumn{4}{|c|}{ SRS of 2011} & \multicolumn{3}{|c|}{ LRS of 2012} \\
\hline & FYM & COMP & CTRL & & FYM & COMP & CTRL \\
\hline Sorghum & 0.99 & 1.03 & 0.88 & & 1.52 & 1.43 & 1.39 \\
\hline Sorghum/dolichos & 1.05 & 1.07 & 1.11 & & 1.53 & 1.47 & 1.44 \\
\hline Sorghum/pigeon pea & 1.04 & 1.06 & 1.01 & & 1.52 & 1.5 & 1.48 \\
\hline Dolichos-Sorghum & 1.04 & 1.044 & 0.98 & & 2.23 & 2.13 & 2.02 \\
\hline Pigeon pea-Sorghum & 1.13 & 1.09 & 1.05 & & 1.62 & 1.58 & 1.40 \\
\hline Mean & & & & & $1.68^{\mathrm{a}}$ & $1.62^{\mathrm{b}}$ & $1.55^{\mathrm{c}}$ \\
\hline \multirow[t]{3}{*}{$\operatorname{LSD}^{0.05}$} & \multicolumn{7}{|c|}{ Cropping systems (CS) } \\
\hline & \multirow{2}{*}{\multicolumn{4}{|c|}{$\begin{array}{l}\text { Organic fertilizers }(\mathrm{OF}) \\
(\mathrm{CS} * \mathrm{OF})\end{array}$}} & & & 0.055 \\
\hline & & & & & & & \\
\hline
\end{tabular}

Note. Within rows and columns, means followed by the same letters are not significantly different at $\mathrm{P}<0.05$. In SRS of 2010, main effects of CS and OF were significant. In LRS of 2011, CS*OF interactions were significant. In SRS of 2011, treatment effects were not significant whereas in LRS of 2012, only main effects of OF were significant 
Table 13. Soil K (cmol/kg) as affected by cropping systems and organic fertilizers in sorghum based cropping systems at Ikombe

\begin{tabular}{|c|c|c|c|c|c|c|c|c|}
\hline \multirow{3}{*}{ Crop } & \multicolumn{8}{|c|}{ Soil K } \\
\hline & \multicolumn{4}{|c|}{ SRS of 2010} & \multicolumn{4}{|c|}{ LRS of 2011} \\
\hline & FYM & COMP & CTRL & Mean & FYM & COMP & CTRL & Mean \\
\hline Sorghum & $0.98^{\mathrm{de}}$ & $1.04^{\text {bcde }}$ & $1.13^{\mathrm{a}}$ & & 1.07 & 1.04 & 1.06 & $1.06^{\mathrm{bc}}$ \\
\hline Sorghum/dolichos & $1.10^{\mathrm{ab}}$ & $1.07^{\mathrm{abc}}$ & $0.97^{\mathrm{e}}$ & & 1.23 & 1.17 & 0.99 & $1.13^{\mathrm{a}}$ \\
\hline Sorghum/pigeon pea & $1.00^{\text {cde }}$ & $0.98^{\mathrm{de}}$ & $1.06^{\mathrm{abcd}}$ & & 1.21 & 1.00 & 1.05 & $1.08^{\mathrm{ab}}$ \\
\hline Dolichos-Sorghum & $1.03^{\text {bcde }}$ & $1.00^{\text {cde }}$ & $1.04^{\text {bcde }}$ & & 1.05 & 1.00 & 0.95 & $1.00^{\mathrm{c}}$ \\
\hline Pigeon pea-Sorghum & $0.98^{\mathrm{de}}$ & $0.96^{\mathrm{e}}$ & $0.99^{\mathrm{de}}$ & & 1.13 & 1.00 & 1.1 & $1.08^{\mathrm{ab}}$ \\
\hline Mean & & & & & $1.14^{\mathrm{a}}$ & $1.04^{\mathrm{b}}$ & $1.03^{\mathrm{b}}$ & \\
\hline \multirow[t]{2}{*}{$\operatorname{LSD}^{0.05}$} & \multicolumn{3}{|c|}{ Cropping systems (CS) } & \multicolumn{5}{|c|}{0.0685} \\
\hline & \multicolumn{3}{|c|}{ Organic fertilizers $(0 \mathrm{~F})$} & \multicolumn{5}{|c|}{0.0816} \\
\hline
\end{tabular}

(CS x OF)

0.0811

\begin{tabular}{|c|c|c|c|c|c|c|c|c|}
\hline \multirow{2}{*}{ Crop } & \multicolumn{4}{|c|}{ SRS of 2011} & \multicolumn{4}{|c|}{ LRS of 2012} \\
\hline & FYM & COMP & CTRL & Mean & FYM & COMP & CTRL & Mean \\
\hline Sorghum & 0.89 & 0.80 & 0.73 & $0.81^{b}$ & 0.67 & 0.65 & 0.63 & $0.65^{\mathrm{d}}$ \\
\hline Sorghum/dolichos & 0.97 & 0.90 & 0.91 & $0.93^{\mathrm{a}}$ & 1.34 & 1.32 & 1.28 & $1.31^{\mathrm{a}}$ \\
\hline Sorghum/pigeon pea & 1.04 & 1.03 & 0.94 & $1.00^{\mathrm{a}}$ & 0.76 & 0.73 & 0.70 & $0.73^{\mathrm{c}}$ \\
\hline Dolichos-Sorghum & 1.04 & 0.90 & 0.98 & $0.97^{\mathrm{a}}$ & 0.93 & 0.92 & 0.98 & $0.94^{\mathrm{d}}$ \\
\hline Pigeon pea-Sorghum & 0.61 & 0.53 & 0.54 & $0.56^{\mathrm{c}}$ & 1.24 & 1.21 & 1.18 & $1.21^{\mathrm{b}}$ \\
\hline Mean & & & & & $0.99^{\mathrm{a}}$ & $0.97^{\mathrm{b}}$ & $0.95^{\mathrm{c}}$ & \\
\hline \multirow[t]{3}{*}{$\operatorname{LSD}^{0.05}$} & \multicolumn{2}{|c|}{ Cropping systems (CS) } & 0.1024 & & & 0.1264 & & \\
\hline & \multicolumn{3}{|c|}{ Organic fertilizers (OF) } & & & 0.0067 & & \\
\hline & $(\mathrm{CS} * \mathrm{O}$ & & & & & & & \\
\hline
\end{tabular}

Note. Within rows and columns, means followed by the same letters are not significantly different at $\mathrm{P}<0.05$. in SRS of 2010, CS*OF interactions were significant whereas in LRS of 2011 and LRS of 2012, main effects of CS and OF were significant. In SRS of 2011, only main effects of C significant.

The soil $\mathrm{K}$ in sorghum based cropping systems increased relative to initial values across seasons and sites (Tables 12 and 13). This could be as a result $\mathrm{K}$ input through residue decomposition as well as organic fertilizers. Further and although soil $\mathrm{K}$ increased in some cases, it was not significantly different from SRS of 2010 and LRS of 2012 in the cassava cropping systems. This could be as a result of the slow build up of organic matter due to incorporation of residues and organic manure which led to an increase in soil K. Kapkiyai et al. (1999) also observed a close relationship between amount of soil organic matter and quantity of available $\mathrm{K}$.

In cassava cropping systems, $\mathrm{K}$ levels were all moderate to high in Katangi $(0.31 \mathrm{cmol} / \mathrm{kg}$ to $1.37 \mathrm{cmol} / \mathrm{kg})$ while at Ikombe they ranged from moderate $(0.33 \mathrm{cmol} / \mathrm{kg})$ to high $(1.88 \mathrm{cmol} / \mathrm{kg})$ (Tables 14 and 15$)$. 
Table 14 . Soil $\mathrm{K}(\mathrm{cmol} / \mathrm{kg})$ as affected by cropping systems and organic fertilizers in cassava based cropping systems at Katangi

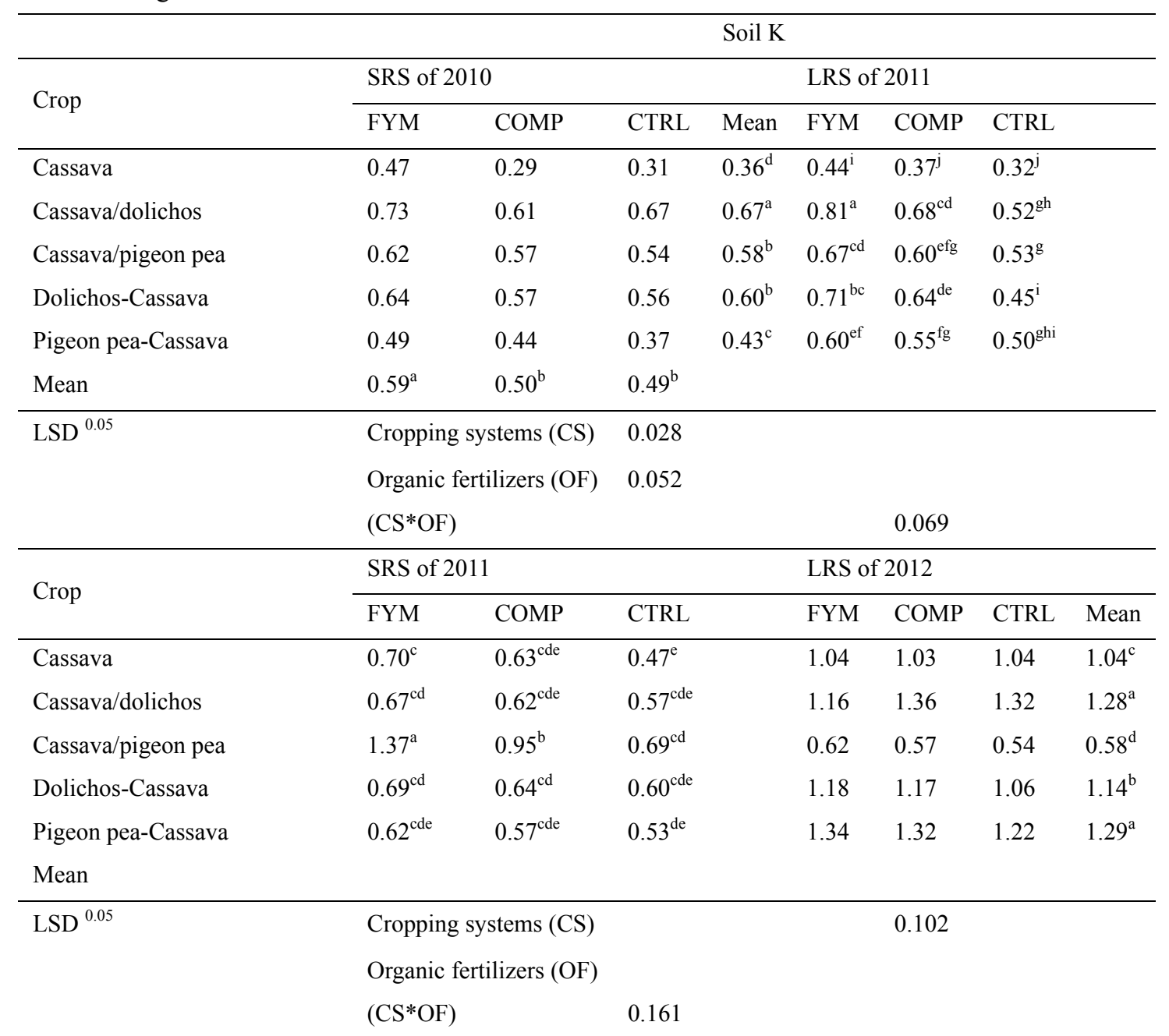

Note. Within rows and columns, means followed by the same letters are not significantly different at $\mathrm{P}<0.05$. In SRS of 2010, main effects of CS and OF were significant whereas in SRS of 2011 and LRS of 2011, CS*OF interactions were significant. In LRS of 2012, only main effects OF were significant. 
Table 15 . Soil $\mathrm{K}(\mathrm{cmol} / \mathrm{kg})$ as affected by cropping systems and organic fertilizers in cassava based cropping systems at Ikombe

\begin{tabular}{|c|c|c|c|c|c|c|c|}
\hline \multirow{3}{*}{ Crop } & \multicolumn{7}{|c|}{ Soil K } \\
\hline & \multicolumn{3}{|c|}{ SRS of 2010} & \multicolumn{4}{|c|}{ LRS of 2011} \\
\hline & FYM & COMP & CTRL & FYM & COMP & CTRL & Mean \\
\hline Cassava & $0.53^{\text {def }}$ & $0.33^{\mathrm{g}}$ & $0.48^{\mathrm{ef}}$ & 0.55 & 0.44 & 0.40 & $0.47^{\mathrm{c}}$ \\
\hline Cassava/dolichos & $0.73^{\mathrm{a}}$ & $0.63^{\mathrm{bc}}$ & $0.50^{\mathrm{ef}}$ & 0.72 & 0.66 & 0.64 & $0.68^{\mathrm{a}}$ \\
\hline Cassava/pigeon pea & $0.67^{\mathrm{ab}}$ & $0.56^{\text {cde }}$ & $0.69^{\mathrm{ab}}$ & 0.72 & 0.59 & 0.67 & $0.66^{\mathrm{a}}$ \\
\hline Dolichos-Cassava & $0.64^{\mathrm{abc}}$ & $0.52^{\mathrm{ef}}$ & $0.62^{\text {bcd }}$ & 0.75 & 0.57 & 0.63 & $0.65^{\mathrm{ab}}$ \\
\hline Pigeon pea-Cassava & $0.51^{\mathrm{ef}}$ & $0.46^{\mathrm{f}}$ & $0.49^{\mathrm{ef}}$ & 0.65 & 0.53 & 0.66 & $0.62^{b}$ \\
\hline Mean & & & & $0.68^{\mathrm{a}}$ & $0.56^{\mathrm{b}}$ & $0.60^{\mathrm{b}}$ & \\
\hline \multirow[t]{3}{*}{$\operatorname{LSD}^{0.05}$} & \multicolumn{5}{|c|}{ Cropping systems (CS) } & 0.045 & \\
\hline & \multicolumn{3}{|c|}{ Organic fertilizers (OF) } & & & 0.042 & \\
\hline & $(\mathrm{CS} \times \mathrm{O}$ & & 0.092 & & & & \\
\hline \multirow{2}{*}{ Crop } & \multicolumn{3}{|c|}{ SRS of 2011} & \multicolumn{4}{|c|}{ LRS of 2012} \\
\hline & FYM & COMP & CTRL & FYM & COMP & CTRL & \\
\hline Cassava & $0.85^{\mathrm{a}}$ & $0.72^{\mathrm{abc}}$ & $0.68^{\text {abcd }}$ & $1.05^{\text {cde }}$ & $1.02^{\text {cde }}$ & $1.01^{\mathrm{de}}$ & \\
\hline Cassava/dolichos & $0.73^{\mathrm{abc}}$ & $0.60^{\mathrm{bcd}}$ & $0.73^{\mathrm{abc}}$ & $1.22^{\mathrm{bcd}}$ & $1.27^{\mathrm{bcd}}$ & $1.45^{\mathrm{b}}$ & \\
\hline Cassava/pigeon pea & $0.35^{\mathrm{e}}$ & $0.49^{\mathrm{de}}$ & $0.72^{\mathrm{abc}}$ & $0.67^{\mathrm{ef}}$ & $0.56^{\mathrm{f}}$ & $0.60^{\mathrm{ef}}$ & \\
\hline Dolichos-Cassava & $0.76^{\mathrm{ab}}$ & $0.63^{b c d}$ & $0.76^{\mathrm{ab}}$ & $1.36^{\mathrm{bcd}}$ & $1.41^{\mathrm{bc}}$ & $1.35^{\mathrm{bcd}}$ & \\
\hline Pigeon pea-Cassava & $0.67^{\mathrm{abcd}}$ & $0.56^{\mathrm{cd}}$ & $0.69^{\mathrm{abc}}$ & $1.88^{\mathrm{a}}$ & $1.60^{\mathrm{ab}}$ & $1.34^{\text {bcd }}$ & \\
\hline \multicolumn{8}{|l|}{ Mean } \\
\hline \multirow[t]{3}{*}{$\operatorname{LSD}^{0.05}$} & \multicolumn{7}{|c|}{ Cropping systems (CS) } \\
\hline & \multicolumn{7}{|c|}{ Organic fertlizers (OF) } \\
\hline & $\mathrm{CS} * \mathrm{OF}$ & & 0.192 & & & & 0.392 \\
\hline
\end{tabular}

Note. Within rows and columns, means followed by the same letters are not significantly different at $\mathrm{P}<0.05$. In SRS of 2011, SRS of 2010 and LRS of 2012, CS*OF interactions were significant. In LRS of 2011, main effects of CS and OF were significant.

Soil K was lower in cassava based cropping systems compared to sorghum based cropping systems. This is attributed to the ability of cassava to remove from soil high quantities of Howeler (2002) observed that cassava is highly responsive to $\mathrm{K}$ and hence extracts high quantities from the soil. These losses are more pronounced especially when biomass is removed as most losses of $\mathrm{K}$ occur through removal of above ground biomass (Smalling, 1993). This could also be the primary reason why soil K values reduced compared to initial values (Table 12). Additionally, removal of above ground biomass could have led to less marked increase in soil organic matter hence $\mathrm{K}$ decline. However, as the seasons progressed, soil $\mathrm{K}$ increased with time probably due to gradual increase in soil organic matter as residue from legumes as well as organic fertilizers contributed to increase in soil organic matter and hence K (Kapkiyai et al., 1999).

The FYM treated plots had higher soil K compared to compost and control respectively across cropping systems and seasons at both sites. This is attributable to slow release of $\mathrm{K}$ by organic fertilizers and higher productivity of crops which could have led to more residue available for decomposition hence more Gikonyo and Smithson (2003), and Kanyanjua et al. (1999) have shown that crop residue return and application of FYM can augment K levels in the soil. Kapkiyai et al. (1999) linked availability of organic matter to available K concluding that practise that lead to build up of organic matter could have a positive effect on soil $\mathrm{K}$.

Only intercropping with dolichos resulted in significantly higher $\mathrm{K}$ compared to monocropping under both cassava and sorghum cropping systems (Tables 12,13, 14 and 15). Higher biomass production, which ensured 
more $\mathrm{K}$ release upon decomposition, may be the reason for the increase. Other cropping systems i.e. intercropping with pigeon pea, and both rotations did not improve soil K. One of the reasons may be that luxury consumption of $\mathrm{K}$ by crops could have ensured that differences in soil $\mathrm{K}$ were not discernible. Results obtained by Bagayoko et al. (1996) while working with pearl millet and cowpea also showed that sole cropping, intercropping and rotation of these crops led to a decline in K levels. Murugappan et al. (1999) similarly reported that crops tend to have luxury consumption of $\mathrm{K}$, which could therefore lead to decline in soil $\mathrm{K}$. Plots where dolichos legume was involved had higher soil $\mathrm{K}$ levels compared to pigeon pea plots. This may be attributed to lower litter quality of pigeon pea, which in turn slows down nutrient release. The superiority of dolichos over pigeon pea in terms of nutrient release upon decomposition has also been proven by Ayoub (1986).

\section{Conclusion}

The current study was carried out to investigate the effect of organic based technologies on soil chemical properties (Organic C, N, P and K) in Katangi and Ikombe divisions of Yatta sub-County during the SRS of 2010 and 2011 and LRS of 2011 and 2012. From the results, Sorghum/dolichos+FYM had highest soil OC in LRS of 2011 at both sites and SRS of 2011 and 2010 at Katangi and Ikombe respectively. Cassava/dolichos+FYM had the highest soil OC in the SRS of 2011 and LRS of 2012 and 2011 at both sites. Sorghum/dolichos+FYM had highest soil N in LRS and SRS of 2011 in Katangi. Cassava-dolichos rotation accumulated highest soil N in SRS of 2010 and LRS of 2011 at both sites. Sorghum/dolichos intercrop accumulated higher soil P during the LRS of 2012 at both sites; and SRS of 2010 and LRS of 2011 in Katangi and Ikombe respectively. Cassava/dolichos intercrop produced higher soil P during the SRS of 2010 at both sites; and LRS of 2011 and SRS of 2011 in Katangi and Ikombe respectively. Higher soil K was observed under sorghum/dolichos intercrop in SRS of 2010 at both sites and LRS of 2011, SRS of 2011 and LRS of 2012 in Ikombe. Cassava/dolichos intercrop also had higher soil K during SRS of 2010, LRS of 2011 at both sites; LRS of 2012 at Katangi and SRS of 2011 at Ikombe.

Integration of legumes into cropping systems and application of organic fertilizers thus improved soil nutrient status in the cassava and sorghum based cropping systems. Intercropping cassava and/or sorghum with dolichos proved better at enhancing soil OC and NPK levels compared to other cropping systems. In addition, if legumes are preferred within cropping system, then use of dolichos in rotation is recommended. Use of organic fertilizers increased soil nutrients with FYM being superior to compost in both cases. To enhance fertility of soil, it is therefore recommended that sorghum and/or cassava intercropped with dolichos alongside application of FYM may be adopted as a sustainable option towards enhanced soil fertility in smallholder farming systems of the semi-arid Yatta sub-County. Further research, under similar experimental settings, is recommended to establish the correlations between soil moisture content and nutrient status.

\section{References}

Adekayode, F. O., \& Ogunkoya, M. O. (2011). Comparative effects of organic compost and NPK fertilizer on soil fertility, yield and quality of amaranth in southwest Nigeria. International Journal of Biological and Chemical Sciences, 5(2), 490-499. http://dx.doi.org/10.4314/ijbcs.v5i2.72087

Adjei-Nsiah, S. (2012). Role of Pigeonpea Cultivation on Soil Fertility and Farming System Sustainability in Ghana. International Journal of Agronomy, 2012, 1-8. http://dx.doi.org/10.1155/2012/702506

Ali, M. A., Molla, M. S. H., Alam, M. R., Mornin, M. A., \& Mannan, M. A. (2009). Effect of combinations of chemical fertilizers and poultry manure on the productivity of crops in the cauliflower-stem amaranth-jute. Bangladesh Journal of Agricultural Research, 34(1), 113-121.

Asafo-Adjei, R. (2004). From imifino to umfuno. A case study foregrounding indigenous agricultural knowledge in school-based curriculum development (Master's thesis). Rhodes University, Grahamstown, South Africa.

Ayoub, A. T. (1986). The potential contribution of some forage crops to the nitrogen budget and animal feed in the Sudan Gezira farming system. Potentials of Forage Legumes in Farming Systems of Sub-Saharan Africa, ILCA, Addis Ababa (pp. 58-68).

Bagayoko, M., Alvey, S., Neumann, G., \& Buerkert, A. (2000). Root-induced increases in soil pH and nutrient availability to field-grown cereals and legumes on acid sandy soils of Sudano-Sahelian West Africa. Plant and Soil, 225(1-2), 117-127. http://dx.doi.org/10.1023/A:1026570406777

Bagayoko, M., Mason, S. C., Traore, S., \& Eskridge, K. M. (1996). Pearl millet/cowpea cropping systems yield and soil nutrient levels. African Crop Sci. J., 4, 453- 462.

Baldock, J. (2009). Building soil carbon for productivity and implications for carbon accounting. Agribusiness 
crop updates. CSIRO Land and Water, Adelaide, Southern Austrralia (SA). Retrieved March 24, 2015, from http://archive.agric.wa.gov.au

Baldwin, K. R., \& Creamer, N. G. (2014). Organic production -cover crops for organic farms. Retrieved September 30, 2014, from http://www.nurserycropscience.info

Blake, G. R., \& Hartge, K. H. (1986). Bulk density, In A. Klute (Ed.), Methods of soil analysis. Part 1, physical and mineralogical methods (2nd ed., Agronomy Monograph No. 9, pp. 363-375). Soil Science Society of America, Madison, WI.

Bouyoucos, G. J. (1962). Hydrometer method improved for making particle size analysis of soil. Agron. J., 54, 464-465. http://dx.doi.org/10.2134/agronj1962.00021962005400050028x

Bremner, J. M., \& Mulvaney, C. S. (1982). Nitrogen-total. In A. L. Page, R. H. Miller \& D. R. Eeney (Eds.), Methods of soil analysis. Part 2. Chemical and microbiological properties (2nd ed., Agronomy Monograph No. 9, pp. 595-624). ASA and SSSA, Madison, WI.

Bwenya, S., \& Terokun, O. A. (2001). Effect of Cassia spectabilis, cowdung and their combination on growth and grain yield of maize (pp. 361-406). Seventh Eastern and Southern Africa Regional Maize Conference, Nairobi, Kenya. February 11-15.

Cassman, K. G., Whitney, A. S., \& Fox, R. L. (1981). Phosphorus requirements of soybean and cowpea as affected by mode of $\mathrm{N}$ nutrition. Agronomy Journal, 73(1), 17-22. http://dx.doi.org/10.2134/agronj1981.00021962007300010005x

Celik, I., Ortas, I., \& Kilic, S. (2004). Effects of compost, mycorrhiza, manure and fertilizer on some physical properties of a Chromoxerert soil. Soil Tillage Res, 78, 59-67. http://dx.doi.org/10.1016/j.still.2004.02.012

Cheruiyot, E. K., Mumera, L. M., Nakhone, L. N., \& Mwonga, S. M. (2001). Rotational effects of grain legumes on maize performance in rift valley, highlands of Kenya. Africa Crop Science Journal, 9(4), 940-949. http://dx.doi.org/10.4314/acsj.v9i4.27588

Eghball, B., \& Power, J. F. (1999). Phosphorus-and Nitrogen-based manure and compost applications corn production and soil phosphorus. Soil Science Society of America Journal, 63(4), 895-901. http://dx.doi.org/10.2136/sssaj1999.634895x

Gachimbi, L. N., Gachimbi, L. N., Van Keulen, H., Thuranira, E. G., Karuku, A. M., De Jager, A., ... Nandwa, S. M. (2005) Nutrient balances at farm level in Machakos (Kenya), using a participatory nutrient monitoring (NUTMON) approach. Land Use Policy, 22(1), 13-22. http://dx.doi.org/10.1016/j.landusepol.2003.07.002

Gichangi, A., Maina, M. P. D., Lelgut, D. K., Kinyua, M. G., Macharia, E., Kamwaga, J., ... Luvonga, J. (2006). Cassava-Grain Legume Inter-Crop: Its Feasibility and Implications on Household Food Security in Kenya.Strengthening Kenya's food security and income. Proceedings of the 10th KARI Biennial Scientific Conference. Kenya Agricultural Research Institute (KARI), November 12-17, 2006, Nairobi, Kenya.

Gikonyo, E. W., \& Smithson, P. C. (2003). Effects of Farmyard Manure, Potassium and their Combinations on Maize Yields in the High and Medium rainfall Areas of Kenya. In A. Bationo (Ed.), Managing Nutrient Cycles to Sustain Soil Fertility in Sub-Sahara Africa (pp. 137-149). Nairobi: Academy Science Publishers (ASP).

Giller, K. E. (2001). Nitrogen fixation in tropical cropping systems. CAB International, Wallingford, Wallingford, UK. http://dx.doi.org/10.1079/9780851994178.0000

Hazelton, P., \& Murphy, B. (2007). Interpreting soil test results what do all the numbers mean? (1st ed.). Collingwood, VIC: CSIRO Publishing. http://dx.doi.org/10.1079/9780851995243.0115

Howeler, R. H. (2002). Cassava mineral nutrition and fertilization. In R. J. Hillocks, J. M. Thresh \& A. C. Bellotti (Eds.), Cas- sava: Biology, Production and Utilization (pp. 115-147). CABI, Wallingford.

IITA (International Institute of Tropical Agriculture). (1990). Cassava in tropical Africa. A reference manual (p. 176).

Ito, O., Matsunaga, R., Tobita, S., Rao, T. P., \& Devi, Y. G. (1993). Spatial distribution of root activity and nitrogen fixation in sorghum/pigeonpea intercropping on an Indian Alfisol. Plant and soil, 155(1), 341-344. http://dx.doi.org/10.1007/BF00025052

Jaetzhold, R., Schmidt, H., Hornetz, B., \& Shisanya, C. (2006). Farm management handbook of Kenya (Vol. II, Subpart C1, II). Eastern province. Natural Conditions and Farm Management Information. Ministry of 
Agriculture, Nairobi, Kenya.

Janssens, M. (2001). Root and tuber crops. In R. H. Raemaekers (Ed.), Crop Production in Tropical Africa (pp. 165-187). Goekint Graphics, Belgium.

Jeranyama, P., Hestermann, O. B., Waddington, S. R., \& Harwood, R. R. (2000). Relay Intercropping of sunnhemp and cowpea into a smallholder maize system in Zimbabwe. Agronomy Journal, 92, $239-244$. http://dx.doi.org/10.2134/agronj2000.922239x

Kanyanjua, S. M., Buresh, R. J., Recke, H., \& Nandwa, S. M. (1999). Potassium status in Kenyan soils and its influence on crop yields: A study to challenge the convention that soils in Kenya have adequate potassium to sustain productivity of major crops. In A poster paper presented at the conference on Managing Plant Nutrition: Towards Maximum Resource Efficiency, Barcelona, Spain. July, 29th.

Kapkiyai, J. J., Karanja, N. K., Qureshi, J. N., Smithson, P. C., \& Woomer, P. L. (1999). Soil organic matter and nutrient dynamics in a Kenyan nitisol under long-term fertilizer and organic input management. Soil Biology and Biochemistry, 31(13), 1773-1782. http://dx.doi.org/10.1016/S0038-0717(99)00088-7

Kherallah, M., Delagde, C., Gabre-Madhin, E., Minot, N., \& Johnson, M. (2002). Reforming agricultural markets in Africa (p. 201). IFPRI and Johns Hopkins University Press, Baltimore.

Kibunja, C. N., Mwaura, F. B., Mugendi, D. N., Kitonyo, E. M., \& Salema, M. P. (2011). Nitrogen (N) Use efficiency under continuous maize-bean cropping system in semi-humid highlands of Kenya. E. Afr. Agric For J., 76, 115-120.

Kouyaté, Z., Diallo, D., N’Diaye, K., \& Ayemou, A. (2012). Influence of crop management systems on soil properties and sorghum yields in the Sahelian zone of Mali. African Journal of Agricultural Research, 7(37), 5217-5223.

Landon, J. R. (1991). Booker Tropical Soil Manual. A Handbook of Soil Survey and Agricultural Land Evaluation in the Tropics and Sub-Tropics (1st ed.). Longman, London.

Lelei, J. J., Onwonga, R. N., \& Freyer, B. (2009). Organic based nutrient management strategies: effect on soil nutrient availability and maize (Zea mays L.) performance in Njoro, Kenya. Afr J Agric Res, 2, 92-99.

Li, H., Shen, J., Zhang, F., Clairotte, M., Drevon, J., Le Cadre, E., \& Hinsinger, P. (2008). Dynamics of phosphorus fractions in the rhizosphere of common bean (Phaseolus vulgaris L.) and durum wheat (Triticum turgidum durum L.) grown in monocropping and intercropping systems. Plant Soil, 312, 139-150. http://dx.doi.org/10.1007/s11104-007-9512-1

Li, L., Li, S. Sun, J., Zhou, L., Bao, X., Zhang, H., \& Zhang, F. (2004). Diversity enhances agricultural productivity via rhizosphere phosphorus facilitation on phosphorus-deficient soils. Proc. Natl. Acad.

Li, L., Tang, C., Rengel, Z., \& Zhang, F. (2003). Chickpea facilitates phosphorus uptake by intercropped wheat from an organic phosphorus source. Plant Soil, 248, 297-303. http://dx.doi.org/10.1023/A:1022389707051

Mapfumo, P., \& Giller, K. E. (2001). Soil Fertility Management Strategies and Practices by Smallholder Farmers in Semi-Arid Areas of Zimbabwe (pp. 1-43). International Crops Research Institute for the Semi-Arid Tropics (ICRISAT).

Marschner, H. (1986). Mineral Nutrition of Higher Plants (p. 674). Acadmic Press, London.

Mc Lean, E. O. (1982). Soil pH and lime requirement, In A. L. Page, R. H. Miller \& D. R. Keeney (Eds.), Methods of soil analysis. Part 2. Chemical and microbio-logical properties (2nd ed., Agronomy Monograph No. 9, pp. 199-224). ASA and SSSA, Madison, WI.

McSweeney, C., New, M., \& Lizcano, G. (2008). UNDP Climate Change Country Profiles-Kenya. UNDP

Mengel, K., Kosegarten, H., Kirkby, E. A., \& Appel, T. (Eds.). (2001). Principles of plant nutrition. Springer. http://dx.doi.org/10.1007/978-94-010-1009-2

Morris, M., Kelly, V. A., Kopicki, R. J., \& Byerlee, D. (2007). Fertilizer use in African agriculture: Lessons learned and good practice guidelines. Washington, DC: World Bank. http://dx.doi.org/10.1596/978-0-8213-6880-0

Mugwira, L. M., \& Murwira, H. K. (1997). Use of Cattle manure to improve soil fertility in Zimbabwe: Past and current research and future research needs. Soil Fertility Network Research Results Working Paper No. 2. CIMMYT, Zimbabwe.

Murphy, J., \& Riley, J. P. (1962). A modied single solution for the determination of phosphate in natural waters. 
Anal. Chim. Acta, 27, 31-36. http://dx.doi.org/10.1016/S0003-2670(00)88444-5

Murugappan, V., Santhy, P., Selvi, D., Muthuvel, P., \& Dhashinsmoorthy, M. (1999). Land degradation due to potassium mining under high intensive cropping in semi arid tropics. Fert. News, 44(5), 75-77.

Mwanga, W. (2004). Low use of fertilizers and low productivity in sub-Saharan Africa. Nutr Cycl Agroecosys, 45, 135-147.

Myaka, F. M., Webster, D. S., Joseph, J. A. G., Donwell, K., Amos, N., Rie, O., ... Høgh, J. H. (2006). Yields and accumulations of $\mathrm{N}$ and $\mathrm{P}$ in farmer-managed intercrops of maize-pigeonpea in semi-arid Africa. Plant and Soil, 285(1-2), 207-220. http://dx.doi.org/10.1007/s11104-006-9006-6

Nelson, D. W., \& Sommers, L. E. (1982). Total carbon, organic carbon, and organic matter. In A. L. Page, R. H. Miller \& D. R. Keeney (Eds.), Methods of Soil Analysis. Part 2.Chemical and Microbiological Properties (2nd ed., Agronomy Monograph No. 9, pp. 539-580). ASA and SSSA, Madison, WI.

Ngome, A. F. E., Becker, M., \& Mtei, K. M. (2012). Leguminous cover crops differentially affect maize yields in three contrasting soil types of Kakamega, Western Kenya. Journal of Agriculture and Rural Development in the Tropics and Subtropics (JARTS), 112(1), 1-10.

Nuruzzaman, M., Lambers, H., Bolland, M. D. A., \& Veneklaas, E. J. (2005). Phosphorus benefits of different grain legume crops to subsequent wheat grown in different soils of Western Australia. Plant Soil, 271, 175-187. http://dx.doi.org/10.1007/s11104-004-2386-6

Ogunwole, J. O., Iwuafor, E. N., Eche, N. M., \& Diels, L. (2009). Effect of organic and inorganic soil amendments on soil physical and chemical properties in a west Africa Savanna agroecosystem. Tropical and Subtropical Agroecosystems, 12(2), 247-255.

Ouédraogo, E., Mando, A., \& Zombré, N. P. (2001). Use of compost to improve soil properties and crop productivity under low input agricultural system in West Africa. Agriculture, ecosystems and Environment, 84(3), 259-266. http://dx.doi.org/10.1016/S0167-8809(00)00246-2

Payne, R. W., Murray, D. A., Harding, S. A., Baird, D. B., \& Soutar, D. M. (2009). GenStat for Windows (12th ed., p. 310). Introduction. VSN International, Hemel Hempstead, UK.

Pholsen, S., \& Sornsungnoen, N. (2004). Effects of nitrogen and potassium rates and planting distances on growth, yield and fodder quality of a forage sorghum (Sorghum bicolor L. Moench). Pak. J. Biol. Sci., 7, 1793-1800. http://dx.doi.org/10.3923/pjbs.2004.1793.1800

Place, F., Barret, C. B., Freeman, H. A., Ramisch, J. J., \& Vanlauwe, B. (2003). Prospects for integrated soil fertility management using organic and inorganic fertlizers: Evidence from small holder African Agricultural systems. Food Policy, 28, 365-378. http://dx.doi.org/10.1016/j.foodpol.2003.08.009

Pypers, P., Sanginga, J. M., Kasereka, B., Walangululu, M., \& Vanlauwe, B. (2011). Increased productivity through integrated soil fertility management in cassava-legume intercropping systems in the highlands of Sud-Kivu, DR Congo. Field Crops Research, 120(1), 76-85. http://dx.doi.org/10.1016/j.fcr.2010.09.004

Rao, M. R., \& Mathuva, M. N. (2000). Legumes for improving maize yields and income in semi-arid Kenya. Agriculture, Ecosystems and Environment, 78, 123-137. http://dx.doi.org/10.1016/S0167-8809(99)00125-5

Rhoades, J. D. (1982). Cation exchange capacity. In A. L. Page, R. H. Miller \& D. R. Keeney (Eds.), Methods of Soil Analysis. Part2. Chemical and Microbiological Properties (2nd ed., Agronomy Monograph No. 9, pp. 149-157). ASA and SSSA, Madison, WI.

Rosen, C. J., \& Bierman, P. M. (2014). Using manure and compost as nutrient sources for fruit and vegetable crops. Retrieved November 14, 2014, from http://www.extension.umn.edu/garden/fruit-vegetable/using-ma nure-and-compost

Rusinamhodzi, L., Murwira, H. K., \& Nyamangara, J. (2006). Cotton-cowpea intercropping and its N2 fixation capacity improves yield of a subsequent maize crop under Zimbabwean rain-fed conditions. Plant and Soil, 287(1-2), 327-336. http://dx.doi.org/10.1007/s11104-006-9080-9

Sanchez, P. A., Shepherd, K. D., Soule, M. J., Place, F. M., Mokwunye, A. U., Buresh, R. J., ... Woomer, P. L. (1997). Soil fertility replenishment in Africa: An investment in natural resource capital. In R. J. Buresh \& P. A. Sanchez (Eds.), Replenishing soil fertility in Africa (SSSA Special Publication). Madison, Wisconsin, U.S.A.: Soil Science Society of America and American Society of Agronomy.

Schlecht, E., Buerkert, A., Tielkes, E., \& Bationo, A. (2006). A critical analysis of challenges and opportunities 
for soil fertility restoration in Sudano-Sahelian West Africa. Nutrient Cycling in Agroecosystems, 76(2-3), 109-136. http://dx.doi.org/10.1007/s10705-005-1670-z

Shava, S. (2000). The use of indigenous plants as food by a rural community in the Eastern Cape: An educational exploration (Master's thesis). Rhodes University, Grahamstown, South Africa.

Shittu, O. S., \& Fasina, A. S. (2004). Cassava yield as affected by different fertilizer model at Ado-Ekiti, Nigeria. Journal of Soil Science, 14, 68-73.

Sieverding, E., \& Leihner, D. E. (1984). Influence of crop rotation and intercropping of cassava with legumes on VA mycorrhizal symbiosis of cassava. Plant and Soil, 80(1), 143-146. http://dx.doi.org/10.1007/BF02232949

Smaling, E. M. A., Nandwa, S. M., \& Janssen, B. J. (1997). Soil Fertility in Africa is at stake. In R. J. Buresh, P. A. Sanchez \& F. Calhoun (Eds.), Replenishing Soil Fertility in Africa (pp. 47-61, SSSA Special Publication Number 71).

Smestad, B. T., Tiessen, H., \& Buresh, R. J. (2002). Short fallows of Tithonia diversifolia and Crotalaria grahamiana for soil fertility improvement in western Kenya. Agrofor. Sys., 55, 181-194. http://dx.doi.org/10.1023/A:1020501627174

Stoorvogel, J. J., \& Smaling, E. M. A. (1998). Research on Soil Fertility Decline in Tropical Environments: Integration of Spatial Scales. Nutrient Cycling in Agroecosystems, 50, 151-58. http://dx.doi.org/10.1023/A:1009732126336

Tiessen, H., Sampaio, E. V. S. B., \& Salcedo, I. H. (2001). Organic matter turnover and management in low input agriculture of NE Brazil. Managing Organic Matter in Tropical Soils: Scope and Limitations (pp. 99-103). Springer, Netherlands.

Zsolnay, A., \& Görlitz, H. (1994). Water extractable organic matter in arable soils: Effects of drought and long-term fertilization. Soil Biology and Biochemistry, 26(9), 1257-1261. http://dx.doi.org/10.1016/0038-0717(94)90151-1

\section{Copyrights}

Copyright for this article is retained by the author(s), with first publication rights granted to the journal.

This is an open-access article distributed under the terms and conditions of the Creative Commons Attribution license (http://creativecommons.org/licenses/by/3.0/). 